\title{
Observations of Thermally Driven Circulations in the Pyrenees: Comparison of Detection Methods and Impact on Atmospheric Composition Measured at a Mountaintop
}

\author{
M. Hulin, F. GHeusi, ${ }^{\text {a }}$ M. Lothon, V. Pont, AND F. LOHOU \\ Laboratoire d'Aérologie, UPS Université Toulouse 3, CNRS (UMR 5560), Toulouse, France \\ M. RAMONET AND M. DELmotTE \\ Laboratoire des Sciences du Climat et de l'Environnement, CEA-CNRS-UVSQ, Université Paris-Saclay, Gif-sur-Yvette, France \\ S. Derrien, G. Athier, Y. Meyerfeld, And Y. Bezombes \\ Laboratoire d'Aérologie, UPS Université Toulouse 3, CNRS (UMR 5560), Toulouse, France \\ P. Augustin \\ Laboratoire de Physico-Chimie de l'Atmosphère, Université Littoral Côte d'Opale and Université Lille Nord de France, \\ CNRS (UMR 8101), Lille, France \\ F. RAVETTA \\ UPMC Université Paris 6, CNRS (UMR 8190), LATMOS-IPSL, Paris, France
}

(Manuscript received 2 October 2017, in final form 14 December 2018)

\begin{abstract}
The atmospheric composition measured at the Pic du Midi high-altitude observatory (2875 m MSL) in the French Pyrenees is frequently affected by upward transport of boundary layer air during anabatic circulations at different scales. The Pyrenean Platform for Observation of the Atmosphere (P2OA) includes two observatories located $28 \mathrm{~km}$ apart: at the Pic du Midi and at a low-altitude site (580 m MSL) located in the plain north of the mountain chain. From a 10-yr-long data series collected at P2OA, three different methods are used to detect thermally induced circulations. The methods are based on observations collected independently at three key locations in the plain-mountain circulation cell: within the altitude return flow above the plain, close to the surface in the plain, and at the mountaintop. The main aims are 1) to present and compare the three detection methods and 2) to evaluate the impact of thermally driven circulations on in situ air composition measurements at the Pic du Midi. The first method uses radar wind measurements at 3000 and $5000 \mathrm{~m}$ above the plain to detect the return flow of the plain-mountain circulation. The second, which is based on surface wind data from the plain site, reveals days during which surface thermally induced winds occur locally. The third method, which is based on surface data at the mountaintop, focuses on diurnal moisture cycles to rank days with decreasing anabatic influence. We then compare the three independent detection methods, discuss possible connections among thermal circulations at different scales and locations, and present an evaluation of their impact on in situ atmospheric composition measurements at Pic du Midi.
\end{abstract}

\footnotetext{
${ }^{\text {a }}$ Current affiliation: Laboratoire d'Aérologie, Université de Toulouse, CNRS, UPS, France.
}

Corresponding author: François Gheusi, francois.gheusi@ aero.obs-mip.fr

\section{Introduction}

High-altitude sites are particularly suitable for the study of free-tropospheric composition and long-term trends. They are generally remote from regional emission sources and most often above the top of the continental boundary layer, allowing measurements to be made that are representative of continental to hemispheric scales (Keeling et al. 1976). Such measurements are 
often termed baseline concentrations (Calvert 1990; Parrish et al. 2014). However, even at mountain sites, air sampling is still conducted at Earth's surface, and measurements may be influenced by local and regional surface effects and emissions, because of vertical transport, convection, and atmospheric turbulence enhanced by mountainous terrain for a variety of reasons (roughness, synoptic lifting, airflow effects, thermally induced circulations, etc.). At the high Alpine site Jungfraujoch (3450 m MSL) in Switzerland, for instance, recent studies with a variety of observations and methods (in situ radon and trace gas measurements; aerosol-layer detection by lidar; Lagrangian particle dispersion model) estimated that the station is under the influence of boundary layer emissions for $40 \%-60 \%$ of the year, with a significant impact on in situ aerosol measurements as compared with free-tropospheric conditions (Collaud-Coen et al. 2011; Herrmann et al. 2015; Poltera et al. 2017). Cristofanelli et al. (2013) analyzed summer ozone $\left(\mathrm{O}_{3}\right)$ observations at a mountain site (2388 m MSL) in the central Italian Apennines and found that the site was significantly affected by air masses from the Mediterranean basin for $32 \%$ of the time. Vertical exchange processes made complex by mountainous terrain (Rotach et al. 2015; Steyn et al. 2013) are less well understood than processes on flat terrain (Zardi and Whiteman 2013). For this reason, it seems necessary to evaluate the impact of vertical transport on measurements of pollutants and to understand to what extent elevated surface stations are representative of the free troposphere.

The current study specifically focuses on thermally induced circulations in mountain terrain. Such diurnal winds typically develop over complex topography and are characterized by a reversal of wind direction two times per day. They are especially favored by clear-sky conditions with weak winds aloft, mostly in summer, when solar heating is maximum (Zaveri et al. 1995). Anabatic flows (upslope, up-valley, or plain-to-mountain flows) occur during daytime when the surface is heated. Conversely, katabatic flows (downslope, down-valley, or mountain-to-plain flows) occur during nighttime when the surface cools. Thermally induced flows develop at several spatial scales along the slopes of mountains, in the valleys, and in the surrounding plains (Mendonca 1969; Vergeiner and Dreiseitl 1987; Schumann 1990; Haiden 2003), and with various time scales (Whiteman 1990, 2000). Slope winds (Vergeiner and Dreiseitl 1987) are produced quasi-instantaneously by horizontal temperature differences between the air mass near the slope and the air mass at the same altitude but outside the slope boundary layer. Along-valley winds (Rampanelli et al. 2004) and plain-mountain winds (Bossert and Cotton 1994) are produced by horizontal pressure gradients along valley axes, or between the mountain and the plain, following temperature differences in the atmosphere. These flows become established several hours after sunrise (Whiteman 2000). In theory, circulation loops are closed by a compensatory return flow higher in the atmosphere. However, return flows are weaker (less than $2 \mathrm{~m} \mathrm{~s}^{-1}$ ) and are often obscured by the synoptic flow (Zardi and Whiteman 2013), and thus they are not always detectable in terrain observations.

Many past studies have demonstrated the direct influence of thermal circulations on pollutant measurements at high-altitude stations. In fact, daytime upward transport of boundary layer air and mixing with freetropospheric air is the most common explanation for diurnal cycles observed for some atmospheric species. A diurnal ozone cycle has been reported, especially during summer, for many high-altitude observatories, most often characterized by minimum concentrations in the middle of the day and maximum concentrations during the night: Mount Mitchell, North Carolina, $2006 \mathrm{~m}$ MSL (Aneja et al. 1994); Mauna Loa, Hawaii, $3400 \mathrm{~m}$ MSL (Oltmans and Levy 1994); Izaña, Canary Islands, 2370 m MSL (Fischer et al. 1998); Jungfraujoch, 3580 m MSL (Schuepbach et al. 2001); Mount Cimone, Italy, 2165 m MSL (Bonasoni et al. 2000; Fischer et al. 2003); Mount Abu, India, 1680 m MSL (Naja et al. 2003); Mount Kenya, Kenya, 3678 m MSL (Henne et al. 2008); Mount Whistler, Canada, 2182 m MSL (Macdonald et al. 2011); and Pic du Midi, $2875 \mathrm{~m}$ MSL, France (Marenco 1986; Gheusi et al. 2011; Tsamalis et al. 2014). Since ozone concentrations increase with height in the first few kilometers of the atmosphere (e.g., Chevalier et al. 2007), upward transport of low-level ozone-poor air mixing with free-tropospheric ozone-rich air results locally in an ozone decrease in the daytime. In some specific cases (e.g., Obrist et al. 2008), however, surrounding polluted valleys with pronounced ozone photoproduction may influence the mountain observatory and generate daytime ozone maxima.

Diurnal cycles are also observed for carbon dioxide $\left(\mathrm{CO}_{2}\right)$ concentrations during the plant growing season (Necki et al. 2003; Keeling et al. 1976; Lin et al. 2017), as photosynthetic activity of the plant cover in the plain and the valleys below the observatory consumes carbon dioxide in the boundary layer. Mixing of $\mathrm{CO}_{2}$-depleted air with free-tropospheric air leads to a decrease of carbon dioxide concentrations in the daytime. In winter, however, a reverse diurnal cycle $\left(\mathrm{CO}_{2}\right.$ being maximum at daytime $)$ may be observed because of uplift of air influenced by plant/soil respiration and anthropogenic activity (Necki et al. 2003; Brooks et al. 2012; DeWekker et al. 2009).

Similarly, other greenhouse gases and boundary layer tracers such as carbon monoxide (Forrer et al. 2000), 
methane (Necki et al. 2003), water vapor (Henne et al. 2005), and radon (Griffiths et al. 2014; Zahorowski et al. 2005) present a diurnal variation with maximum content during daytime and a minimum at night. Indeed, boundary layer air contains more water vapor and more gaseous species from anthropogenic and natural surface emissions (Atlas and Ridley 1996; Forrer et al. 2000). Radon being a reliable tracer of continental surface influence (Chambers et al. 2013), anabatic winds are also associated with a radon concentration increase in the afternoon.

In many cases, aerosol variables (total number concentration, absorption and scattering coefficients, equivalent black carbon mass concentration) show similar diurnal variations (e.g., Sellegri et al. 2010; Collaud-Coen et al. 2011). The observed afternoon maxima are partly driven by upward transport of boundary layer air to the station; however, the interpretation is more complex, especially because of new particle formation (nucleation), which may occur in situ in the free troposphere or in the valley atmosphere (Venzac et al. 2008; Boulon et al. 2011; Bianchi et al. 2016) and even dominate the aerosol total number concentration (Bukowiecki et al. 2016). Aerosol nucleation is indeed known to be favored at mountain sites because of increased amount of UV radiation and lower temperatures decreasing the nucleation barrier, among other reasons (Boulon et al. 2011; Neitola et al. 2011; García et al. 2014; Rose et al. 2015; Hallar et al. 2016). Further analyses revealed that the number concentration of the accumulation mode (particle diameter above $90 \mathrm{~nm}$ ) and the absorption coefficient are less ambiguous proxies of the boundary layer influence and primary emissions than the total number concentration (Venzac et al. 2008; Bukowiecki et al. 2016; Collaud Coen et al. 2018). At the Jungfraujoch, it was also recognized that, in frequent cases in the warm season, the nighttime minimum of aerosol variables is not representative of the remote free troposphere but of the residual ventilation layer from the previous day above the Alps (Collaud-Coen et al. 2011; Bukowiecki et al. 2016; Poltera et al. 2017).

In this context, there is an ongoing effort to characterize local and regional influences near high-altitude observatories. In the Alps, the atmospheric chemical composition and variability have been studied extensively. However, this is not the case for the Pyrenees. Few measurement campaigns have been carried out, with the aim of documenting the influence of meteorological conditions on the atmospheric composition at the Pic du Midi (PDM) observatory: Atmospheric Pollution in the Pyrenees (PAP; Ezcurra et al. 2013), Pic 2005 (Gheusi et al. 2011), and Pic 2010 (Gheusi et al. 2016). Ezcurra et al. (2013) present experimental data from April to October 2004 from the PAP experiment.
They investigated the local flow effects on the mean ozone concentrations. Among other things, their observations revealed a diurnal cycle of ozone content with a minimum around midday at high-altitude stations. Mountain thermal winds emerged as the most appropriate hypothesis to explain this situation. The Pic 2005 intensive measurement campaign carried out in June and July 2005 with the aim of a better understanding of the spatiotemporal structure of the ozone field near PDM. From the Pic 2005 data, Gheusi et al. (2011) and Tsamalis et al. (2014) showed and estimated the impact of thermally induced pumping of air from the boundary layer on in situ measurements, particularly concerning ozone, at PDM during daytime. The Pic 2010 campaign carried out in July 2010 (Gheusi et al. 2016) documented and quantified the orographic ventilation of the Pyrenees (plain-mountain and boundary layer-free troposphere exchanges). For instance, a return flow of the plainmountain circulation was evidenced above the plain on 10 July 2010. Observations for this day are presented in the body of this article, because this very illustrative case actually motivated the design and use of the return-flow detection method presented in this study. From the findings of the Pic 2005 and 2010 campaigns, Gheusi et al. (2011) and Gheusi et al. (2016) pointed out the need to establish a climatology of the observed phenomena.

Here, we present a study based on a long data series (10 years) collected at the Pyrenean Platform for Observation of the Atmosphere (P2OA; http://p2oa.aero.obs-mip.fr) to document the thermally driven circulations at different scales and over all seasons. We present different methods for detecting thermal circulations at three key locations of the plain-mountain circulation loop. The main aims of this paper are 1) to present and compare the three independent detection methods and 2) to evaluate the impact of thermally driven flows on in situ atmospheric gas and aerosol measurements at PDM.

The geographical context and datasets are described in section 2. Section 3 presents the three detection methods developed and used in this study. The results are discussed in section 4 , and some conclusions are drawn and perspectives suggested in section 5 .

\section{Site description and data}

\section{a. Geographical context}

The P2OA is a research platform for atmospheric observations affiliated with the University of Toulouse. It is located on the northern side of the central Pyrenees, halfway $(200 \mathrm{~km})$ between the Mediterranean Sea and the Atlantic Ocean (Bay of Biscay), and close to the 


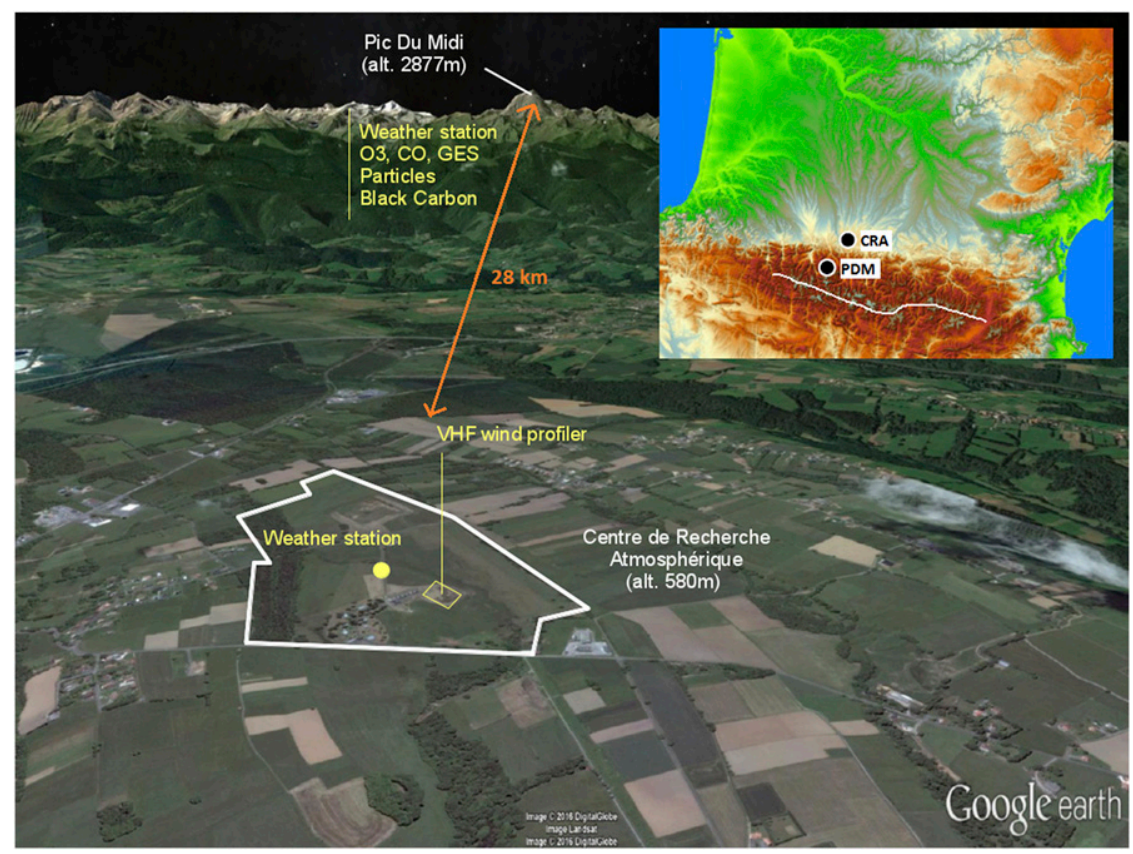

FIG. 1. Location and Google Earth three-dimensional representation of the P2OA area, as viewed from the northeast. The locations of the measurement sites CRA and PDM are shown in the inserted map. The white line in the map sketches the Pyrenean watershed.

Spanish border (less than $50 \mathrm{~km}$ ). It is composed of two sites (Fig. 1):

1) the PDM observatory, a high-altitude site $(2875 \mathrm{~m}$ MSL) that is particularly suitable for the study of the free troposphere (Henne et al. 2010; Collaud Coen et al. 2018), and

2) the Centre de Recherches Atmosphériques (CRA) of Lannemezan (580 m MSL), $28 \mathrm{~km}$ northeast of PDM, which is a mostly flat and extensive rural site located on a plateau in the Pyrenean foothills.

The Pyrenees have relatively simple geometry (a 400-km barrier running from west-northwest to east-southeast; Fig. 1). Coupled observations at PDM and CRA thus allow atmospheric processes to be investigated as they develop in a quasi two-dimensional terrain configuration. The P2OA is situated almost on the Greenwich meridian (longitude $0^{\circ}$ ), and therefore the local solar time matches the coordinated universal time (UTC) used throughout this study.

\section{b. Data}

A wide range of meteorological and other variables characterizing the physical properties and chemical composition of the atmosphere at PDM and CRA are routinely monitored and are available through an Internet database (http://p2oa.aero.obs-mip.fr). This study is based on some of this database. The meteorological measurements (temperature, relative humidity, pressure, and surface wind components) are performed in situ at CRA and PDM with standard weather stations. At PDM, in situ concentrations of atmospheric gases $\left(\mathrm{O}_{3}, \mathrm{CO}, \mathrm{CO}_{2}\right.$, and $\mathrm{CH}_{4}$ ) and aerosols [total suspended particle (TSP) number concentration $N$; equivalent black carbon mass concentration (eqBC)] are determined with standard commercial analyzers [the $\mathrm{O}_{3}$ analyzer and condensation particle counter are detailed, e.g., in Gheusi et al. (2011); the greenhouse gas analyzer is described in Crosson (2008), Yver Kwok et al. (2015), and Staufer et al. (2016); and the aethalometer is described in Weingartner et al. (2003) and Arnott et al. (2005)]. Concentration data that are obviously contaminated by local combustion products were flagged and ruled out from the analyses. A VHF $(45 \mathrm{MHz})$ wind profiler at CRA gives the three wind components between 1.5 and $16 \mathrm{~km}$ above the ground with a vertical resolution of $375 \mathrm{~m}$ and an accuracy of $0.5 \mathrm{~m} \mathrm{~s}^{-1}$ [the VHF profiler characteristics are detailed in Campistron et al. (1999) and Campistron et al. (2001)]. All measurements performed are listed with specific details in Table 1. Because data were collected at different time resolutions, synchronized hourly averages are used for all data considered in this study.

The considered data mostly cover 10 years between January 2006 and December 2015, a period that was chosen because it had maximum data coverage. To correctly apply our three detection methods, entire days were discarded when any instrument readings (wind profiler or surface wind measurement at CRA or humidity 
TABLE 1. Instrumentation and measurement characteristics. See Fig. 1 for locations of the measurement sites.

\begin{tabular}{|c|c|c|c|c|c|c|}
\hline Measured variable & Instrument & Start date & $\begin{array}{l}\text { Time } \\
\text { resolution }\end{array}$ & Type & Site & Studied period \\
\hline $\begin{array}{l}\text { Temperature } T \text { and } \\
\text { relative humidity }\end{array}$ & $\begin{array}{l}\text { Automatic weather station } \\
\text { (Vaisala, Inc., QMH } 102 \text { sensor) }\end{array}$ & Jun 2004 & $5 \min$ & In situ & PDM & Jan 2006-Dec 2015 \\
\hline Pressure $P$ & $\begin{array}{l}\text { Automatic weather station } \\
\text { (Vaisala PMT16A sensor) }\end{array}$ & Jun 2004 & $5 \min$ & In situ & PDM & Jan 2006-Dec 2015 \\
\hline $\begin{array}{l}\text { Wind }(u, v, \mathrm{WD} \text {, } \\
\text { and WS) }\end{array}$ & $\begin{array}{l}\text { Automatic weather station (before } \\
29 \text { Oct 2014: Vaisala WS } 425 \text { sonic } \\
\text { sensor; after } 29 \text { Oct 2014: Metek } \\
\text { GmbH 3D USA-1 sonic sensor) }\end{array}$ & Jun 2004 & $5 \mathrm{~min}$ & In situ & PDM & Jan 2006-Dec 2015 \\
\hline $\mathrm{O}_{3}$ & $\begin{array}{l}\text { UV analyzer (Thermo Electron } \\
\text { Corp. models } 49 \mathrm{c} \text { and } 49 \mathrm{i})\end{array}$ & Apr 1999 & $5 \mathrm{~min}$ & In situ & PDM & Jan 2006-Dec 2015 \\
\hline $\begin{array}{l}\text { Greenhouse gases } \\
\quad\left(\mathrm{CO} ; \mathrm{CO}_{2} ; \mathrm{CH}_{4}\right)\end{array}$ & $\begin{array}{l}\text { Cavity ring-down spectroscopy } \\
\text { analyzer (Picarro, Inc., G2401) }\end{array}$ & May 2014 & $4 \mathrm{~s}$ & In situ & PDM & May 2014-Dec 2015 \\
\hline eqBC & $\begin{array}{l}\text { Aethalometer (Magee Scientific } \\
\text { Co. AE 31) }\end{array}$ & Aug 2013 & $15 \mathrm{~min}$ & In situ & PDM & Aug 2013-Dec 2015 \\
\hline TSP no. concentration $N$ & $\begin{array}{l}\text { Condensation particle counter } \\
\text { (TSI, Inc., 3010) }\end{array}$ & Jul 2008 & $5 \mathrm{~min}$ & In situ & PDM & Jul 2008-Dec 2015 \\
\hline $\begin{array}{l}\text { Wind ( } u, v, \mathrm{WD} \text {, } \\
\text { and WS) }\end{array}$ & $\begin{array}{l}\text { Automatic weather station } \\
\text { (Degreane Horizon SAS } \\
\text { MIRIA; Météo-France) }\end{array}$ & Feb 1990 & $1 \mathrm{~min}$ & In situ & CRA & Jan 2006-Dec 2015 \\
\hline $\begin{array}{l}\text { Wind }(u, v, \mathrm{WD}, \\
\text { and WS) }\end{array}$ & VHF wind profiler & Jun 2001 & $15 \mathrm{~min}$ & $\begin{array}{l}\text { Remote } \\
\text { sensing }\end{array}$ & CRA & Jan 2006-Dec 2015 \\
\hline
\end{tabular}

measurement at PDM) had more than $25 \%$ of missing hourly data within the day in question. As a result, we kept $54 \%$ of days in the 10 -yr period. We checked that these days were uniformly distributed over the 10 years. It was verified that each month of the year, and each hour of the day, were approximately uniformly represented (between $44 \%$ and $63 \%$ for the months, and between $89 \%$ and $94 \%$ for the hours).

\section{c. Meteorological context}

The regional climate of southwestern France prevails at the P2OA, but with a more pronounced influence of the mountain barrier than is observed farther north in the plain. The mesoscale and boundary layer dynamics at CRA is frequently modulated by the presence of the mountains south of the site, with thermal effects occurring between the plain and the mountain. Located $200 \mathrm{~km}$ east of the Atlantic coast, the observatory is most often exposed to oceanic westerlies or northwesterlies. The occurrence of south foehn is also common, affecting the north side of the mountain chain, in cases of southerly midtropospheric flow ahead of fronts coming from the Atlantic Ocean. South foehn drives continental air from the Iberian Peninsula. The P2OA may occasionally be influenced by easterly Mediterranean flow, when mesoscale low pressure systems form over the Mediterranean Sea.

Figure 2 shows wind statistics (wind roses) for 2006-15 at the P2OA. The VHF wind data at $3000 \mathrm{~m}$ above sea level (Figs. 2a,b) are most of the time representative of the synoptic flow in the midtroposphere. As expected at midlatitude in Europe, westerlies are dominant. However, separating daytime and nighttime reveals the influence of thermally induced effects resulting in more frequent winds in the northwest quadrant $\left(270^{\circ}-360^{\circ}\right)$ at night than in the daytime, when the southwest sector $\left(180^{\circ}-270^{\circ}\right)$ prevails.

The PDM is also under the influence of the westerly synoptic flow, but the local influence of the topography and also the presence of buildings at the station (especially a major mask $150 \mathrm{~m}$ northwest of the station-a 120-m high TV antenna) make wind observations most frequent in the southwest quadrant (Figs. 2c,d). Nevertheless, a contrast exists between day and night, related to thermally driven winds: the wind typically oscillates between a wide westerly sector $\left(225^{\circ}-315^{\circ}\right)$ at night and a southerly sector $\left(135^{\circ}-225^{\circ}\right)$ in the daytime.

Surface winds at CRA (Figs. 2e,f) show the frequent synoptic influence of westerlies guided along the Pyrenees but also the occurrence of thermally induced winds, influenced by the local topography. Nocturnal katabatic wind from the south-southeast $\left(130^{\circ}-190^{\circ}\right)$ is especially frequent at night (Fig. 2f), whereas the daytime anabatic wind blows from the east-northeast $\left(330^{\circ}-110^{\circ}\right.$, Fig. 2 e).

\section{d. Thermally induced winds and thermal cell at the P2OA site}

Several authors-for example, Whiteman (2000) and Dosio et al. (2002) —observe and present the plainmountain daytime circulation as a thermal cell composed of a low-level anabatic flow toward the mountains 
Wind rose VHF3000m (2006-2015, daytime (11h-14h))

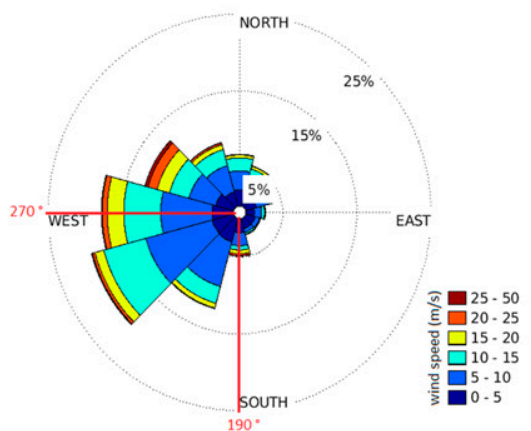

(a)

Wind rose PDM (2006-2015, daytime (11h-14h))

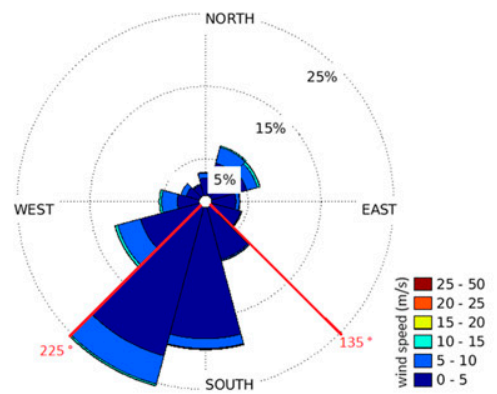

(c)

Wind rose CRA (2006-2015, daytime (11h-14h))

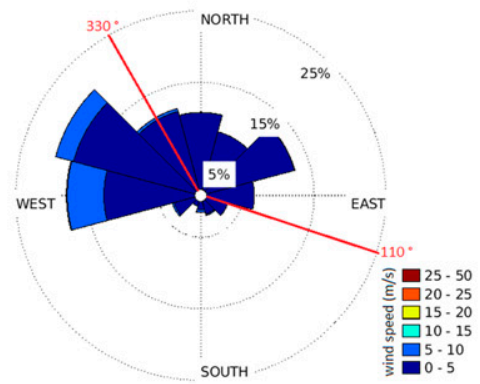

(e)
Wind rose VHF3000m (2006-2015, nighttime (23h-02h))

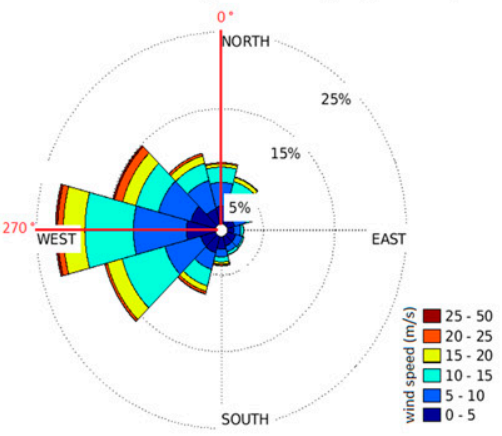

(b)

Wind rose PDM (2006-2015, nighttime (23h-02h))

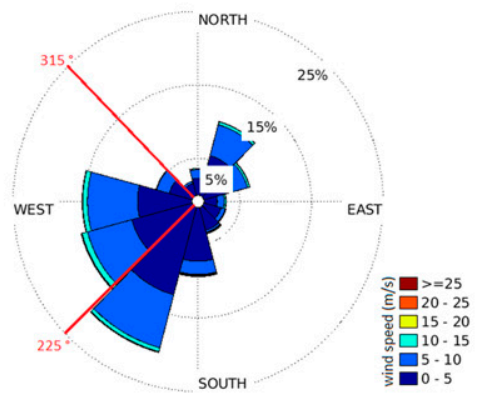

(d)

Wind rose CRA (2006-2015, nighttime (23h-02h))

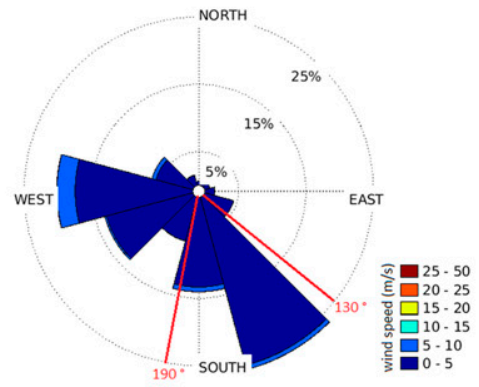

FIG. 2. Wind roses for (left) daytime and (right) nighttime at the three measurement locations: (a),(b) VHF $3000 \mathrm{~m}$, (c),(d) PDM, (e),(f) CRA. The wind sectors outlined in red correspond to those considered in Fig. 12 and section $4 \mathrm{~d}$.

and a return flow at altitude above the convective boundary layer, which subsides over the plain. As illustrated below, such a large-scale plain-mountain circulation can be well observed at P2OA.

Although mentioned in the literature as being weak and sometimes hard to observe (Whiteman 2000; Zardi and Whiteman 2013), the upper-level return flow above the plain is nevertheless often visible in VHF wind profiles above the CRA. The Pic 2010 campaign offered a well-documented case of return flow on 10 July 2010, with available radio soundings in support of the VHF observation (Fig. 3 and 4 ). As shown by Fig. 3a, a 

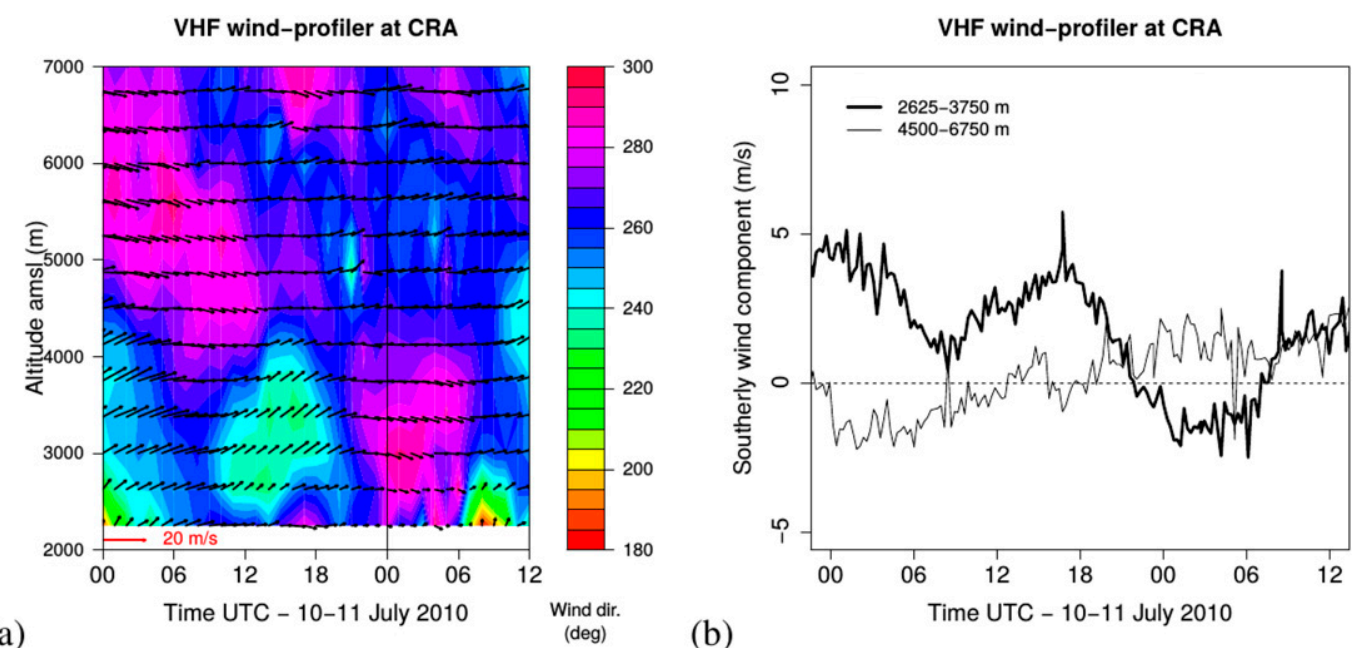

FIG. 3. (a) Horizontal wind vectors retrieved from the VHF wind-profiler at CRA, from 0000 UTC 10 Jul 2010 to 1200 UTC $11 \mathrm{Jul} 2010$. The color code represents the wind direction. The length scale of the vectors is given in red in the bottom-left corner. (b) Southerly component of the VHF wind vertically averaged between 2675 and $3750 \mathrm{~m}$ MSL (thick curve) and between 4500 and $6750 \mathrm{~m}$ (thin curve).

quasi-steady $5-10 \mathrm{~m} \mathrm{~s}^{-1}$ westerly flow prevailed above $5000 \mathrm{~m}$ for about $36 \mathrm{~h}$ from 0000 UTC 10 July 2010 . Over the mountains, fair weather conditions prevailed throughout the period. Over the foothills, lower clouds and light rain were present in the morning (until 1000 UTC) but then dissipated. At lower levels, a remarkable feature in Fig. 3a is the core of southwesterly wind blowing between 2250 and $4000 \mathrm{~m} \mathrm{MSL}$, from the late morning to the early evening of 10 July. This flow resulted from the combination of the synoptic westerly flow and an added southerly component. During the following night (until 0600 UTC 11 July), the situation reversed: a northerly component (i.e., toward the mountains) was detected in the same altitude range. In this layer, the diurnal oscillation of the southerly component between 0600 UTC 10 July and 0600 UTC 11 July is clearly visible in Fig. 3b, while above $(4500-7000 \mathrm{~m})$ the southerly component remained weak, showing only a slow synoptic trend. A plausible interpretation for this observation is that the daytime southerly component corresponds to the elevated return flow of a thermally driven plain-to-mountain circulation that developed near the Pyrenees; conversely, the northerly component at night might be the elevated counterpart of the nighttime mountain-to-plain flow at lower levels.

Support for the hypothesis of thermally driven plainmountain circulation is given by two radiosondes launched almost simultaneously around 1500 UTC from CRA and Tramezaygues (TRM), a valley-bottom site located at $1444 \mathrm{~m}$ MSL, $4 \mathrm{~km}$ east of PDM (Fig. 4). For convenience, layers have been subjectively delimited and numbered (from 1 to 3 ) in the figure. The westerly synoptic flow is clearly visible from both soundings above $4000 \mathrm{~m}$ MSL (layer 1; Fig. 4a). The southwesterly flow detected by the VHF radar below $4000 \mathrm{~m}$ is also evidenced by the soundings between 3000 and $4000 \mathrm{~m}$ above both the plain (CRA) and the mountains (TRM) (Figs. 4a,b; layer 2). TRM being located southwest of CRA, a Lagrangian connection thus existed between the two sites for layer 2 (transport time of $60-80 \mathrm{~min}$ ), which is evidenced by almost-matching specific humidity profiles in layer 2 (Fig. 4c). Below $3000 \mathrm{~m}$, the atmosphere in the mountains was homogeneous and moist (Fig. 4c, TRM), while the export layer from the Pyrenees characterized by southwesterly wind and enhanced humidity was visible above CRA down to $2200 \mathrm{~m}$ MSL (layer 3). This is a clear indication that the southwesterly flow layer detected by the VHF profiler is related to thermal pumping of moist air over the Pyrenees.

From these observations, we hypothesize a daytime plain-mountain circulation at P2OA as sketched in Fig. 5. Besides in the altitude return flow (VHF profiles), this circulation may also be experienced at two other key locations of the thermal cell: close to the surface in the plain, and close to the surface at the mountaintop. For this reason, we also consider in situ surface measurements at CRA and PDM. However, surface observation at CRA may also reflect thermal winds at a more local scale (e.g., between the plain and the foothills only), and may also be influenced by the up-/downvalley wind system of the major Aure Valley located about $10 \mathrm{~km}$ to the south of CRA. At PDM, local upslope winds carrying air from the closest valleys may also be detected. The scale at which surface phenomena 

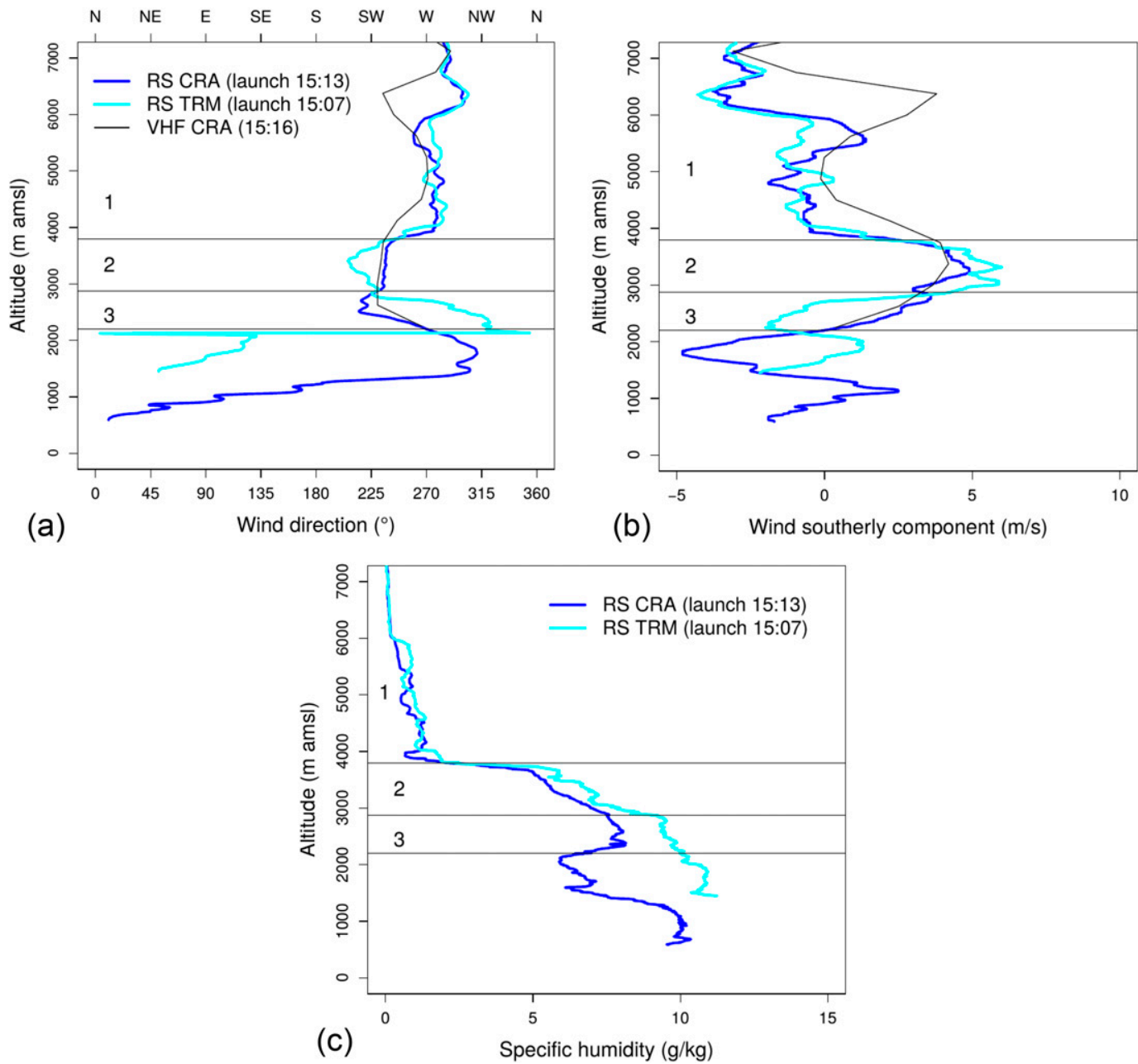

FIG. 4. Tropospheric profiles around 1500 UTC $10 \mathrm{Jul} 2010$ from radio soundings at CRA and TRM and from the VHF wind-profiler at CRA: (a) wind direction, (b) wind southerly component, and (c) specific humidity $\left(\mathrm{g} \mathrm{kg}^{-1}\right)$. The inserted numbers and horizontal lines identify layers that are described in the text.

occur at CRA or PDM is thus more ambiguous and will be discussed below.

\section{Detection methods}

Three methods are developed and exploited in this study to document the thermally induced circulations at the P2OA in three locations of the plain-mountain circulation cell (Fig. 5) and to evaluate their impact on pollutant measurements at PDM. The three methods are fully independent, in the sense that they are based on independent datasets and different criteria.

The first approach is based on radar wind measurement at 3000 and $5000 \mathrm{~m}$ above CRA. Its purpose is to detect global circulation days, that is, days during which the thermal cell is well established at the mountainplain scale and a return flow is present at altitude. The second method, which is based on surface data at CRA, reveals days during which surface thermally driven winds occur locally at CRA. The third method is based on mountaintop surface data at PDM. It focuses on the influence of anabatic flows on the air composition at PDM and uses a quantitative measure of this impact to rank days from the most to the least anabatic. The three approaches are detailed in this section.

\section{a. Method 1: Radar wind measurement at 3000 and $5000 \mathrm{~m}$}

Method 1, also called "altitude detection method," allows the largest scale circulation-that is, the mountainplain circulation - to be studied. It is based on the observation of the return flow of the thermal cell visible at $3000 \mathrm{~m}$ above CRA using wind measurements made by a wind profiler (section $2 \mathrm{~d}$ ). In daytime, this return flow 


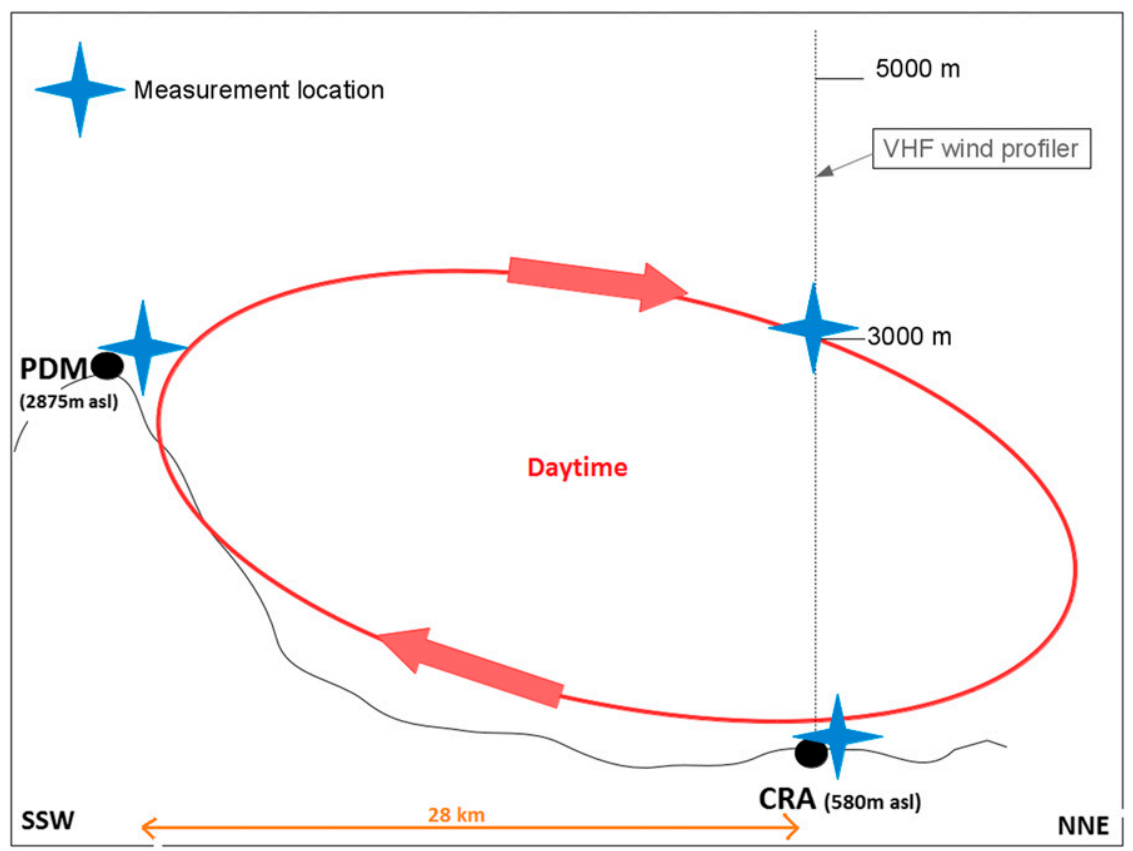

FIG. 5. Schematic of the thermal circulation cell at P2OA in daytime and the three key measurement locations that support the three different methods.

adds a southerly component to the synoptic flow at $3000 \mathrm{~m}$, which modifies wind direction and/or speed in a specific layer. Since upper layers are not affected by this phenomenon, a wind shear is established between $3000 \mathrm{~m}$ and the layers above. At nighttime, we might expect a northerly wind component at $3000 \mathrm{~m}$ when katabatic winds start to blow, but this process is actually not always observed at this altitude. The stable boundary layer being shallower at nighttime, this return flow probably occurs lower. A subjective selection of about 20 days meeting optimal weather conditions for a well-established plainmountain circulation (clear-sky conditions, no rain, and weak synoptic forcing), was primarily studied to determine detection criteria. For example, Fig. 6 shows wind characteristics at 3000 and $5000 \mathrm{~m}$ above CRA for two specific days among this selection. We can see (Fig. 6a) that on 14 August 2006 in daytime (1000-1600) the initially westerly flow at $3000 \mathrm{~m}$ deviates northward and then, at night realigns with the synoptic flow, whereas the flow at $5000 \mathrm{~m}$ is unaffected. On 7 January 2006 (Fig. 6b) the southerly flow at $3000 \mathrm{~m}$ does not deviate but is accelerated by the southerly component of the thermal return flow (in addition to the positive synoptic trend observed at $5000 \mathrm{~m}$ ). By paying careful attention to these illustrative days, it was possible to specify the selection criteria used in method 1 , which are the following:

- A first filter is applied to detect a difference in either wind direction or wind speed between 3000 and $5000 \mathrm{~m}$ in daytime (1000-1600). Depending on the synoptic wind direction sector, we search for a minimum difference of $15^{\circ}$ in wind direction (WD), or of $10 \%$ in wind speed (WS), between these two altitudes for at least one hour during the time slot:

1) In the east sector $\left(15^{\circ}<\mathrm{WD}_{5000}<165^{\circ}\right), \mathrm{WD}_{3000}$ must be between $\mathrm{WD}_{5000}+15^{\circ}$ and $360^{\circ}-\left(\mathrm{WD}_{5000}+15^{\circ}\right)$.

2) In the west sector $\left(195^{\circ}<\mathrm{WD}_{5000}<345^{\circ}\right), \mathrm{WD}_{3000}$ must be between $360^{\circ}-\left(\mathrm{WD}_{5000}-15^{\circ}\right)$ and $\mathrm{WD}_{5000}-15^{\circ}$.

3) In the south sector $\left(165^{\circ}<\mathrm{WD}_{5000}<195^{\circ}\right), \mathrm{WS}_{3000}$ must be higher than $\mathrm{WS}_{5000}$ by at least $10 \%$.

4) In the north sector $\left(345^{\circ}<\mathrm{WD}_{5000}\right.$ or $\left.\mathrm{WD}_{5000}<15^{\circ}\right)$, $\mathrm{WS}_{3000}$ must be lower than $\mathrm{WS}_{5000}$ by at least $10 \%$.

- Because similar changes might arise accidentally from mechanisms other than thermal pumping, we apply a second filter to check the existence of a night-daynight alternation of the south-north wind component at $3000 \mathrm{~m}\left(v_{3000}\right)$. To be more specific, during thermal circulation days, a diurnal cycle of the deviation of $v_{3000}$ from its diurnal mean must be observed, with a negative mean value over both nighttime periods (0000-0500 and 2000-2300) and a positive mean value over the daytime period (1000-1600).

For the first filter, the criteria have to be met for at least one hour during the time slot considered (1000-1600). A sensitivity study showed that increasing the number of hours required in the slot from one to two reduces the 


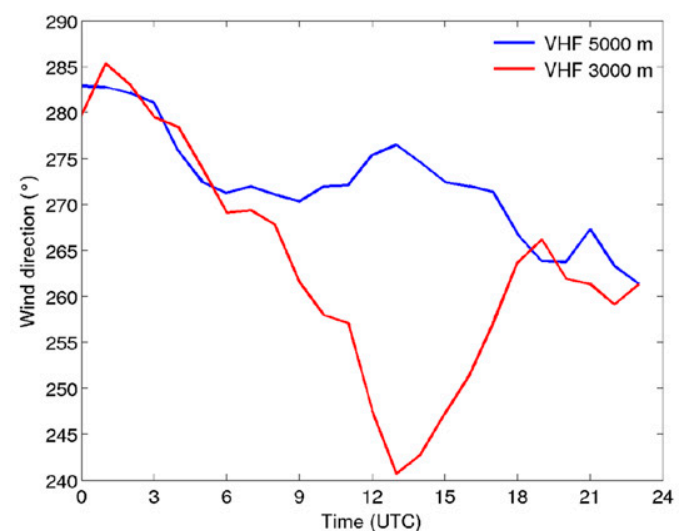

(a) 14 August 2006

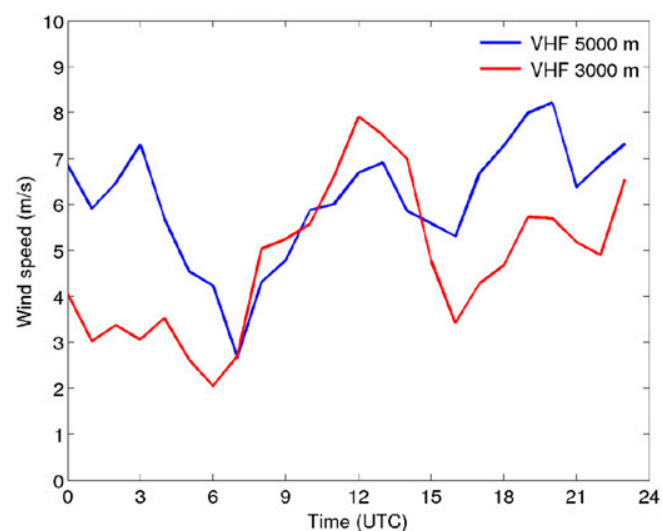

(b) 7 January 2006

FIG. 6. Typical diurnal evolution of (a) wind direction (14 Aug 2006) or (b) wind speed (7 Jan 2006) as observed from the VHF radar at 3000 and $5000 \mathrm{~m}$ MSL.

percentage of selected days from $27 \%$ to $22 \%$ of the total number of days (1986). However, a visual inspection revealed that the correctly rejected days represented only $2 \%$ of the total number of days. A major part of the percentage reduction is thus composed of false negatives. Therefore, the requirement of only one hour has been preferentially selected.

\section{b. Method 2: Surface data at CRA}

Surface winds at CRA are influenced by thermal effects because of the proximity of the Pyrenees. As well as the plain-mountain circulation, more local thermal effects such as valley winds in the Aure Valley to the south of CRA, or slope winds over the foothills, may affect the site.

The "surface detection method," the second approach, focuses on thermally driven flows at CRA by studying changes in surface wind direction. Surface anabatic winds in daytime are typically northeasterly at CRA, while katabatic winds at night are south-southeasterly (Figs. 2e,f). Figure 7 presents surface wind direction changes driven by thermal circulation at CRA during a typical day. Our criteria are based on a previous characterization of the surface winds at CRA by Barneoud et al. (2010). These authors first considered one year of data (June 2001-June 2002) qualitatively to spot thermally induced flow situations and define criteria. Then, they achieved a quantitative study over 6 years (1996-2001) to evaluate the frequency and seasonality of such events. The implementation of our method 2 is based on this study and also on two more recent studies (Jiménez and Cuxart 2014, 2016) on the influence of the Aure Valley at the CRA. As a synthesis of those previous works, our method 2 selects days that meet both of the following criteria:

1) surface wind direction between $330^{\circ}$ and $110^{\circ}$ at daytime (1100-1400) and
2) surface wind direction between $130^{\circ}$ and $190^{\circ}$ at nighttime (0000-0200 and 2100-2300).

Since turbulence may cause many wind variations, the direction criterion must be met for at least one hour during each slot. Again, a sensitivity study showed that increasing from 1 to 2 the number of hours required in the slot discarded $2 \%$ of true negatives but reduced the number of selected days from $27 \%$ to $7 \%$ of the total number of days (1986). The wrong rejection of a large number of true anabatic days would be even worse than in method 1.

\section{c. Method 3: Ranking anabatic days from surface data at PDM}

The third approach consists of ranking anabatic days using an anabatic flow indicator measured in situ at

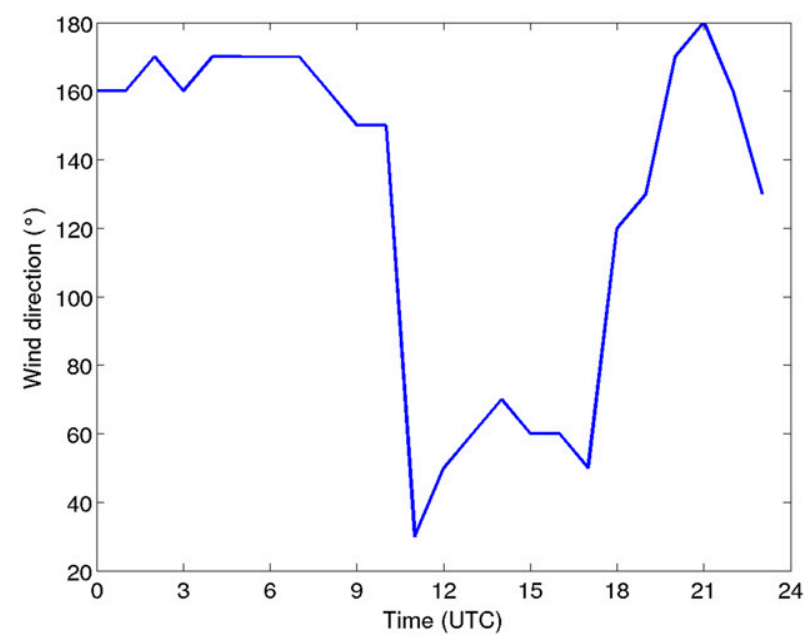

FIG. 7. Typical diurnal evolution of wind direction observed near the surface at CRA (15 Oct 2006). 
PDM. This is a direct application of the analysis method proposed by Griffiths et al. (2014). Using observations of radon-222 and a new analysis method, these authors quantified the land surface influence at Jungfraujoch and detected the presence of anabatic winds. Central to their method is the recognition that anabatic winds are associated with a cyclic diurnal variation of boundary layer tracer concentrations at the mountaintop, peaking in the afternoon. Generally speaking, the procedure consists of computing the radon concentration mean diurnal cycle from all observed days, serving as reference, and then evaluating the impact of removing each day separately on the amplitude of the diurnal cycle obtained from all remaining days. All days are then ranked from the most-anabatic day (removing it reduces the amplitude of the diurnal cycle most), to the least-anabatic day (removing it reduces the amplitude of the diurnal cycle least). All details of this method are presented in Griffiths et al. (2014).

In our case, since radon was not yet measured at the PDM observatory between 2006 and 2015, specific humidity was chosen as the anabatic indicator-following the alternative suggested in Griffiths et al. (2014). We apply the same method on a time series split into days (24-h segments beginning at 0000 UTC). Specific humidity has high day-to-day variability and a season-to-season variability. Therefore, to partly eliminate biases due to synoptic and seasonal trends, the method is applied to specific humidity anomaly with respect to the mean for the current day. Then, the method steps are as follow:

1) Compute the diurnal composite ${ }^{1}$ of specific humidity anomaly over all considered days - resulting in 24 hourly values (positive or negative) - and then compute the mean square of these 24 values to quantify the amplitude of this composite.

2) For each day,

(i) compute a diurnal composite from all days in the set except the current one and then

(ii) calculate the mean square value of this new diurnal composite and compare it with the value obtained in step 1.

3) The day that most reduces the composite's mean square value is removed from the set and ordered in the first place of the anabatic ranking.

4) Steps 1-3 are repeated until the day set is exhausted.

The days are thus ordered by degree of anabatic influence. The plot in the insert of Fig. 8 represents the diurnal composites of specific humidity anomaly according to the

\footnotetext{
${ }^{1}$ The term "composite" is used for "mean diurnal cycle" hereinafter in this article.
}

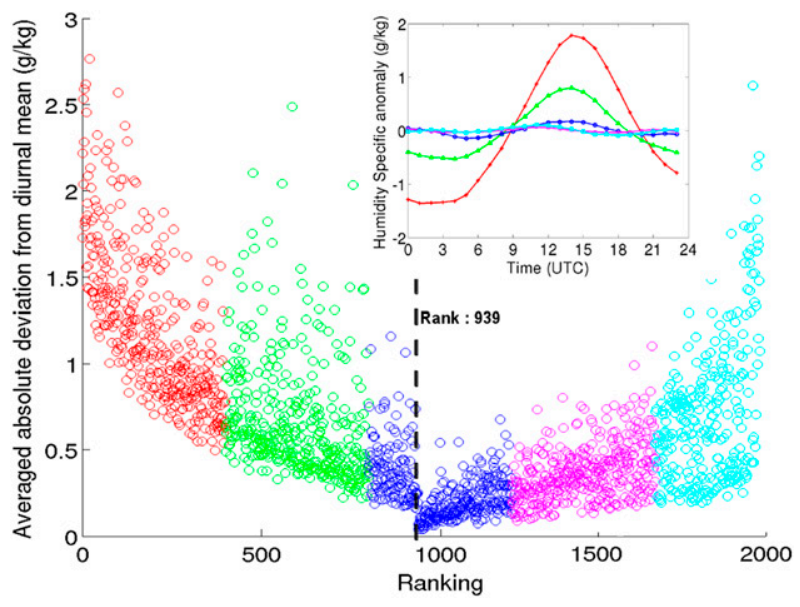

FIG. 8. Intraday specific humidity variation vs anabatic rank. The insert shows diurnal composites of specific humidity anomaly according to different ranges of ranks, using the same color code as in the main plot.

different ranges of ranks. It shows the progression of the diurnal cycle of humidity in agreement with the method construction. The amplitude of the diurnal cycle decreases with increasing rank number, until the diurnal cycle vanishes. The use of humidity anomaly does not eliminate any risk of misclassification, since processes other than thermally driven flows, for example, synoptic trends, could accidentally produce humidity variation in phase with the composite. However, synoptic trends are not correlated with the solar cycle, and therefore the weight of misclassified days in statistics should remain small.

The averaged absolute deviation from the diurnal mean is plotted as function of the anabatic rank in Fig. 8. The quantity along the $y$ axis in Fig. 8 summarizes how much the specific humidity fluctuates around its diurnal mean during the day in question. This plot reveals a rank for which the diurnal specific humidity fluctuation reaches a minimum-rank 939 in our case. Before this rank, the humidity fluctuation is mostly due to the daytime anabatic influence and thus decreases overall from rank 1 to rank 939. The jump between rank 937 and 939 may appear as an unexpected discontinuity. It is actually explained by the fact that once we get to cases in which there is no longer a diurnal cycle in phase with the anabatic-katabatic oscillation, any kind of intradiurnal variabilities may occur, with no link (and arbitrary phasing) with anabatic transport. Those are then ranked from very small variability to much larger variability. This also explains why humidity fluctuation tends to increase after rank 939, especially in the largest ranks, as the result of random intraday variability, leading on average to a noisy, small-amplitude composite. Such an increase is also observed with radon in Griffiths et al. (2014), but to a lesser extent. A detailed 
TABLE 2. Total number of days selected by the three methods, and corresponding fractions of the total set.

\begin{tabular}{lccr}
\hline \hline & Selected & Unselected & Total \\
\hline Method 1: altitude detection & 544 days $(27.4 \%)$ & 1442 days $(72.6 \%)$ & 1986 days $(100 \%)$ \\
Method 2: surface detection & 547 (days $(27.5 \%)$ & 1439 days $(72.5 \%)$ & 1986 days $(100 \%)$ \\
Overlap (selected by both 1 and 2) & 201 days $(10.1 \%)$ & - & 1986 days $(100 \%)$ \\
Excluded (rejected by both 1 and 2) & - & 1096 days $(55.2 \%)$ & 1986 days $(100 \%)$ \\
Method 3: ranking method & 939 days $(47.3 \%)$ & 1047 days $(52.7 \%)$ & 1986 days $(100 \%)$ \\
\hline
\end{tabular}

explanation concerning the radon fluctuation increase is given in Griffiths et al. (2014), but similar arguments are valid in the case that is presented here. To separate anabatic and nonanabatic days, we adopted the same definition of threshold rank as in Griffiths et al. (2014): namely, the rank of minimum specific humidity variation (939).

\section{Results}

\section{a. Sets of days selected by the three methods}

Three distinct sets of selected days result from the independent application of the three methods over the period under study. The numbers and proportions of days in each selection are given in Table 2. Method 1 selected around $27 \%$ of days with a large-scale thermal cell detected at altitude above the plain out of the total set. Method 2 also selected $27 \%$ of days with surface thermally induced flow, in agreement with the results obtained by Barneoud et al. (2010), who reported a frequency of around $20 \%$, and with a more recent study (Román-Cascón et al. 2019), which gave similar occurrence frequencies, between 25 and 30\%. For the northern Alpine foreland (Munich, Germany, area), Graf et al. (2016) found an occurrence rate of $17 \%$ (62 days $\mathrm{yr}^{-1}$ ) with day-night surface wind oscillation, by means of a 20 -yr regional climate simulation.

Notably, the overlap of the two sets represents only $10 \%$ of all days. However, it represents about $40 \%$ of one set or the other, and $20 \%$ of their union. This day selection, called the "overlap" set, reflects conditions favorable to the development of both a return flow at altitude (which is the result of large-scale mountain pumping) and surface anabatic wind at CRA. This reveals that, in many cases, the two phenomena occur independently. For instance, during sunny winter days, a thermal gradient may exist locally between CRA and the lowest foothills, but the snow cover at higher altitudes reduces the development of thermal pumping at the scale of the chain. It is also possible that a return flow forms lower, in the blind range of the VHF profiler (within $1500 \mathrm{~m}$ above the ground). Conversely, a largescale return flow may exist at altitude but a low-level cloud cover over the foothills may prevent the development of surface anabatic wind at CRA. In such case, it may be speculated that anabatic winds develop at least higher in the valleys.

The union of the two sets selected by methods 1 and 2 includes $45 \%$ of all days. The fact that the union set is much larger than the overlap reveals that thermally induced winds do not always occur as in the idealized sketch of Fig. 5, but in some cases arise more locally, with a different vertical span, or in a more complex way.

The overlap set guarantees days with a well-extended plain-mountain circulation including the foothills, whereas the "union" set includes days with potential influence of anabatic winds at any scale or location. Its complementary set, corresponding to days rejected by both methods 1 and $2(55 \%)$, is called the "excluded" set. It gives the best likelihood of being free of any anabatic influence.

For method 3, the determination of a threshold rank (here 939), as defined in Griffiths et al. (2014), makes it possible to distinguish anabatic days, defined as days ranked before the threshold. Such days amount to $47 \%$, which is close to the proportion ( $45 \%)$ obtained by using water vapor as boundary layer tracer in Griffiths et al. (2014) for the Jungfraujoch. The proportion is notably more than with methods 1 and 2 taken separately, because method 3 cannot separate anabatic influences due to the plain-mountain circulation from influences of more local upslope of up-valley winds. Thus, it is more relevant to compare the proportion given by method 3 with the result from the union set.

Figure 9 gives the distribution of days from method-1, method-2, and overlap selections as a function of the rank given by method 3 . Seventy percent of the method1 selection, $60 \%$ of the method- 2 selection, and $75 \%$ of the overlap set are classified before the threshold rank. This means that days detected by method 1 , method 2 , or both methods present a much higher probability of anabatic influence at PDM than random days. This result also reveals a significant number of outliers, however, that is, days with a return flow at altitude and/or surface anabatic wind at CRA but no anabatic humidity signature at PDM (e.g., if the lower atmosphere is vertically well mixed, vertical transport has no signature in terms of local composition). Beyond this, a number of 


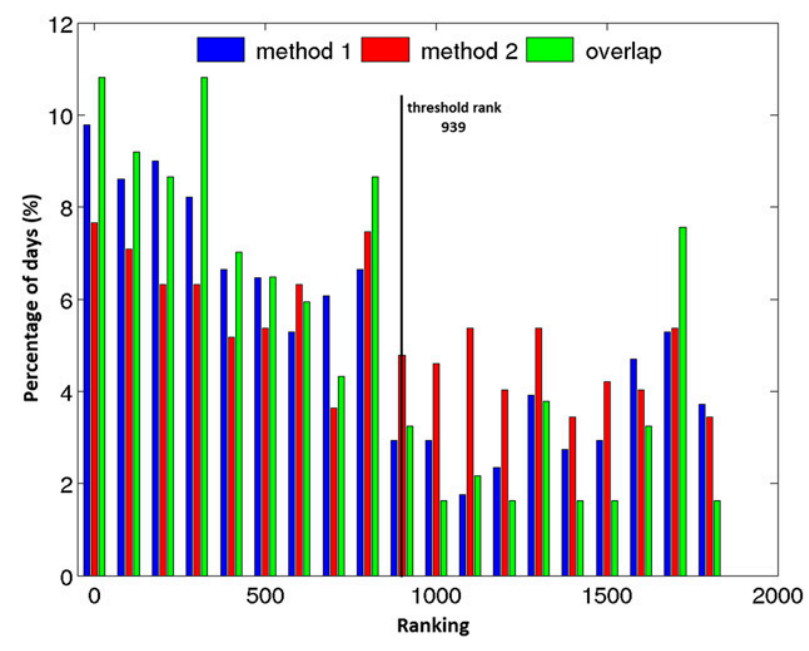

FIG. 9. Percentage of days selected in method 1, method 2, and the overlap set, classified in bins of 100 consecutive ranks from method 3. The threshold rank (939) in method 3 is indicated by a vertical line.

inconsistencies can also be explained by selection errors (false positives or negatives) in any of the methods.

The consistency among the results obtained from the three methods is further discussed in the following four sections, which address the question of the return-flow occurrence and intensity, the seasonality of the thermally driven circulations, the diurnal cycle of the winds, and the impact on atmospheric composition.

\section{b. Composite VHF profiles and altitude return flow}

The vertical structure and diurnal evolution of the wind profiles as observed by the VHF radar above CRA are investigated here, considering different diurnal composites based on different day selections. More specifically, the composites shown in Fig. 10 were calculated on the basis of anomalies of the wind southerly component with respect to the current day mean, in order to remove most of the synoptic component of the wind, and focus on thermally induced variations, especially those related to a return flow.

Figure 10a shows the 10-yr (2006-15) composite including all available data. The diurnal variation is weak (less than $\pm 0.5 \mathrm{~m} \mathrm{~s}^{-1}$ of amplitude), is mostly uniform in the vertical direction from 2000 to $6000 \mathrm{~m}$, and has a strong 12-h-period component, suggesting a tidal origin (Diaz et al. 2010). The composite for the summer season (June-September of 2006-15, Fig. 10b) shows a similar structure, but a 24-h pattern with a stronger amplitude tends to appear, especially below $4000 \mathrm{~m}$.

This pattern emerges clearly in the composite that is based on the method-1 selection (Fig. 10c), with an amplitude as high as $2 \mathrm{~m} \mathrm{~s}^{-1}$ between 2500 and $3500 \mathrm{~m}$.
This was expected because method 1 was specifically designed to detect a daytime positive anomaly of the southerly wind component at $3000 \mathrm{~m}$. This figure thus reveals the vertical and temporal structure of the altitude return flow, occurring mostly between 2500 and $4000 \mathrm{~m}$ and exhibiting a maximum between 1200 and 1500 UTC. In this day selection, the daily maximum of southerly wind anomaly is most probably found at $1400 \mathrm{UTC} \pm 3 \mathrm{~h}$ $(1 \mathrm{std} \mathrm{dev})$ and at $3225 \mathrm{~m} \mathrm{MSL} \pm 600 \mathrm{~m}(1 \mathrm{std} \mathrm{dev})$, that is, within 2 vertical levels of the VHF profiler.

The composite that is based on the method-2 selection (Fig. 10d) shows a similar pattern but of lesser amplitude (about $1 \mathrm{~m} \mathrm{~s}^{-1}$ ), which is in line with the small overlap found between the method- 1 and method- 2 sets, as discussed in the previous section. Nevertheless, method 2 does better than simply selecting the summer season. The composite that is based on the overlap set (not shown) is very similar to the method- 1 composite, since the overlap set is a subset of the method-1 selection.

More interesting are the composites that are based on an increasing number of anabatic days ranked in method 3 (the 200 and 939 most-anabatic days in Figs. 10e and 10f, respectively). The return flow is visible in both figures but has a much larger amplitude (above $1.5 \mathrm{~m} \mathrm{~s}^{-1}$ ) if only the 200 most-anabatic days are considered. This, taken with Fig. 9, clearly establishes a correlation between the strength of the anabatic influence in situ at PDM and the occurrence of a return flow above the plain. When a return flow is generated by the mountain chain, the PDM observatory is situated in the return-flow layer (e.g., in Fig. 4), because the Pyrenean watershed is located farther south (Fig. 1). A similar terrain configuration exists for the Zugspitze observatory in the Bavarian Alps (Germany), and the same conclusion is mentioned in Lugauer and Winkler (2005). Anabatic influence affects PDM in such situations, and thus method 3 is expected to detect not only local anabatic influences but also the influence of large-scale return flow.

\section{c. Seasonality}

Figure 11 presents the seasonal distribution of the days selected by the three methods. The days selected by methods 1 and 3 follow the same seasonal trend with a minimum frequency in winter (less than $4 \%$ in November, December, and January), rising in spring (between $9 \%$ and $12 \%$ in April, May, and June) to reach a maximum in late summer and early autumn ( $\sim 13 \%$ in August and September). Unsurprisingly, this distribution is consistent with higher likelihood of plain-mountain circulation, upvalley winds, and upslope winds during warm seasons. Beyond this, it has been shown (section $4 \mathrm{~b}$ and Fig. 10) that method 3 is more efficient than a seasonal selection for spotting days with a return flow, even though it is less specifically designed than method 1 to this goal. 

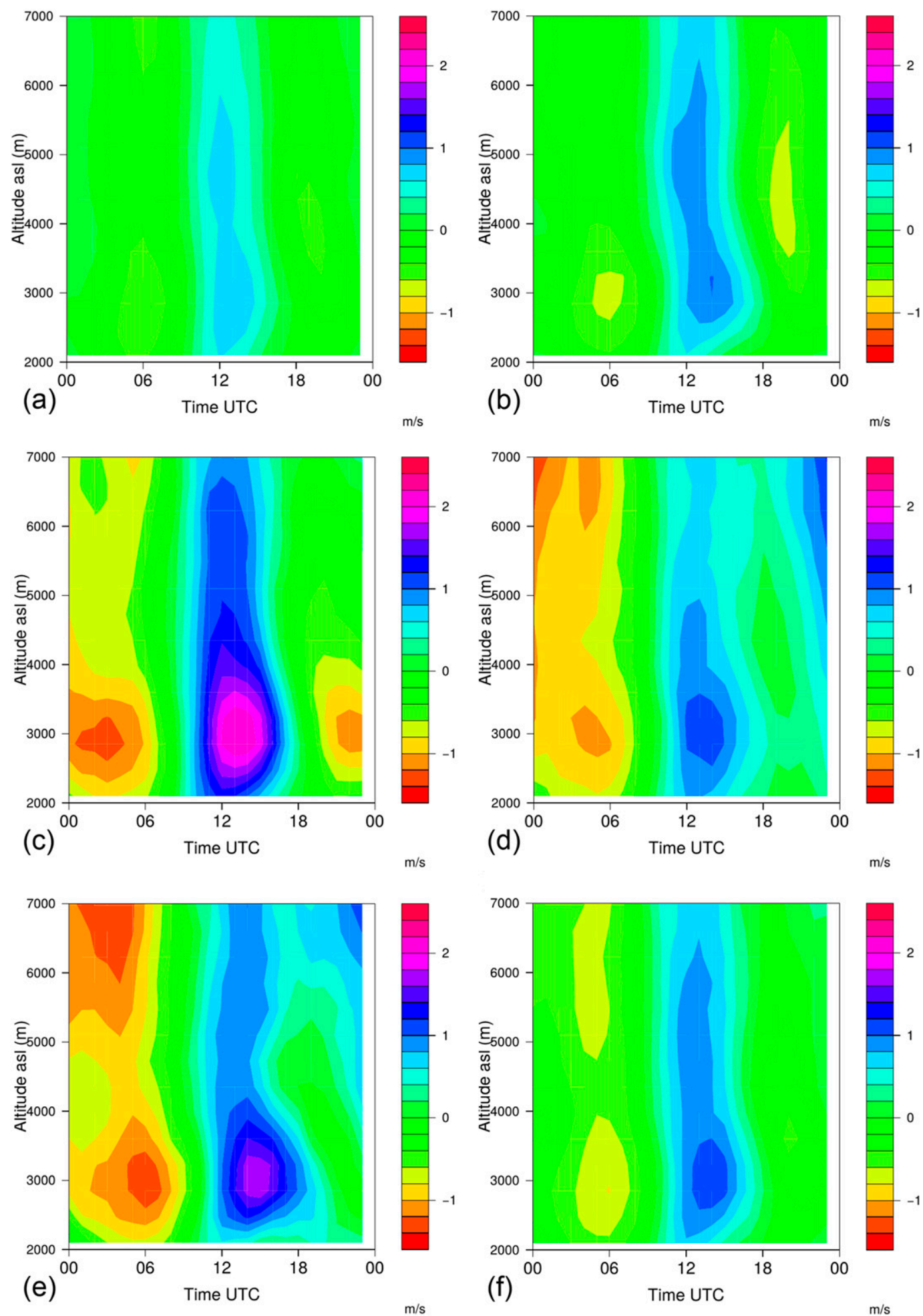

FIG. 10. Diurnal composites of the VHF south-north (cross mountain) wind-component daily anomaly for different day sets: (a) all data for 2006-15, (b) the summer season (June-September of 2006-15), (c) day selection by method 1 , (d) day selection by method 2, and day selection by method 3 for the (e) 200 and (f) 939 most-anabatic days. 


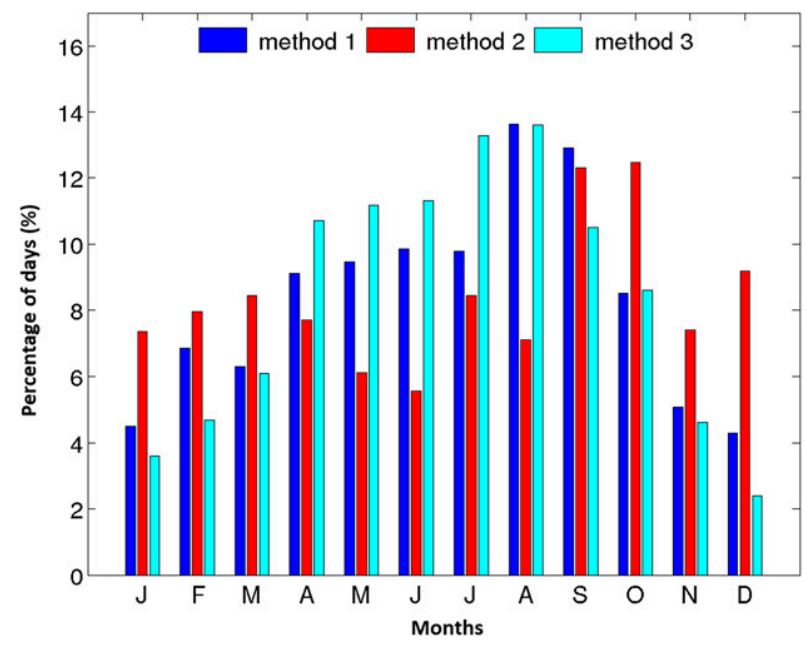

FIG. 11. Monthly distribution of selected days by methods 1,2 , and 3 (939 most-anabatic days).

The seasonality of the method-2 selection differs from the previous ones. The occurrence frequencies are more uniformly distributed throughout the year, but a maximum occurs in autumn (around 12\% in September and October) and a minimum occurs in late spring and early summer (between $6 \%$ and $8 \%$ ). It may be surprising to find no summer maximum, when valley winds and mountain-plain winds are most frequent. As compared with thermally induced winds at altitude, here the seasonality is altered because of low-level weather impacting the surface in the plain. This is the case in May, June, and July, when the lower troposphere is often moist [rain and specific humidity are maximum during this period over the foothills (statistics not shown)] while fair weather may be more frequently found at altitude. In winter and autumn, anticyclonic dry air masses lead to shallow thermally driven winds (which could be detected by method 2 but are associated with no large-scale cell, or at least no return flow detectable at $3000 \mathrm{~m}$ ). Autumn is also the season of maximum occurrence of south foehn. The deep penetration of foehn down to the surface at CRA is relatively rare and occurs only in the most intense situations. In contrast, it is common to observe counterflow surface anabatic wind at CRA and in the Aure Valley while moderate foehn is blowing aloft. In our VHF data, for instance, south-to-southwesterly $\left(180^{\circ}-240^{\circ}\right)$ wind of more than $5 \mathrm{~m} \mathrm{~s}^{-1}$ is found at $3000 \mathrm{~m}$ for $29 \%$ of the days ( 160 of 547 ) selected by method 2; wind of more than $10 \mathrm{~m} \mathrm{~s}^{-1}$ in the same sector is found for $15 \%$ of the days ( 80 of 547 ).

\section{d. Diurnal distribution of wind occurrences}

In this section we further compare the methods through the study of the diurnal cycle of wind direction at the three key locations. The thermally induced circulations are indeed associated with diurnal alternation between wind sectors that are specific to each location. The choice of wind sectors representative of the anabatic or katabatic influence at each location was driven by the wind roses (Fig. 2) and is consistent with the direction criteria used for methods 1 and 2. Figure 12 presents the diurnal evolution of occurrence frequency in those wind sectors, for the three locations. In addition, a distinction is made between anabatic and nonanabatic days, using day sets selected or rejected by the different methods. More specifically, we consider the overlap set composed of the 201 days selected by both methods 1 and 2 and compare it with the "first" set composed of the 200 most-anabatic days ranked by method 3. For sets of unselected days, we compare the excluded set combining the days rejected by both methods 1 and 2 (1096 days) with the "last" set composed of the 900 least-anabatic days from method 3 . Thus defined, the sets to be compared have approximately same numbers of elements.

At first glance, diurnal cycles are evident for the selected day sets (overlap and first), whereas they are absent or much weaker for the rejected day sets (excluded and last) at the three locations. Furthermore, the wind direction frequencies are almost the same, especially for the overlap and first sets. It can be concluded that both filters are able to discriminate the same type of thermally induced events, even though the resulting day sets do not match perfectly (section $4 \mathrm{a}$ ).

For altitude wind at $3000 \mathrm{~m}$ MSL above CRA (VHF), on selected days (Fig. 12a), frequencies of wind direction show a diurnal cycle with a decrease of northwesterly wind occurrence and an increase of southwesterly wind occurrence in daytime, particularly between 1200 and 1800. The eastern sector (not shown in the histograms) remains rare (less than $15 \%$ and $10 \%$ for the overlap and first sets, respectively), and its frequency is constant through the day. A comparison of the overlap and first frequencies reveals larger occurrence of northwesterlies (15\%-30\% more) for the first days. This difference can be due to the method- 2 construction, which systematically discards westerly wind. In rejected sets, no cycle is observed (Fig. 12b), occurrences remaining almost constant through the day.

Figures $12 \mathrm{c}$ and $12 \mathrm{~d}$ focus on surface wind at PDM. Results are similar to those noted previously for the wind at $3000 \mathrm{~m}$ above CRA. However, the wind direction sectors are different. The typical wind sectors at this location are west (night) and south (day). A diurnal cycle is also observed for the rejected sets but to a much lesser extent (variation of frequencies of only 10\%). Local slope or valley winds around the peak may explain the existence of this low cycle during days without return flow at altitude or surface anabatic wind at CRA. 


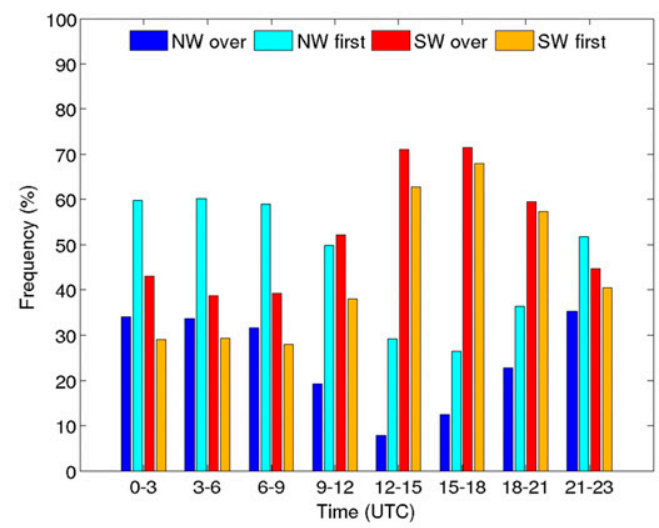

(a) Selected day sets - VHF 3000 m

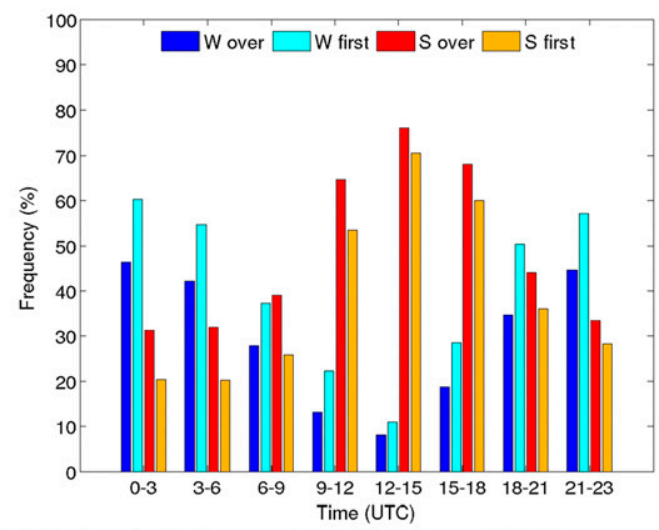

(c) Selected day sets - Surface PDM

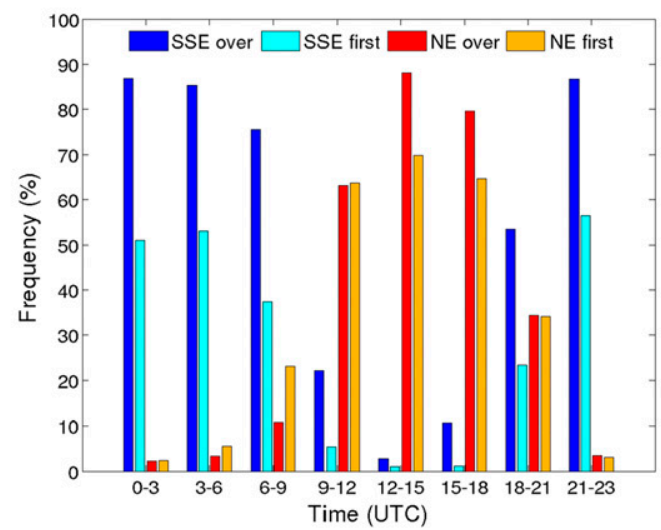

(e) Selected day sets - Surface CRA

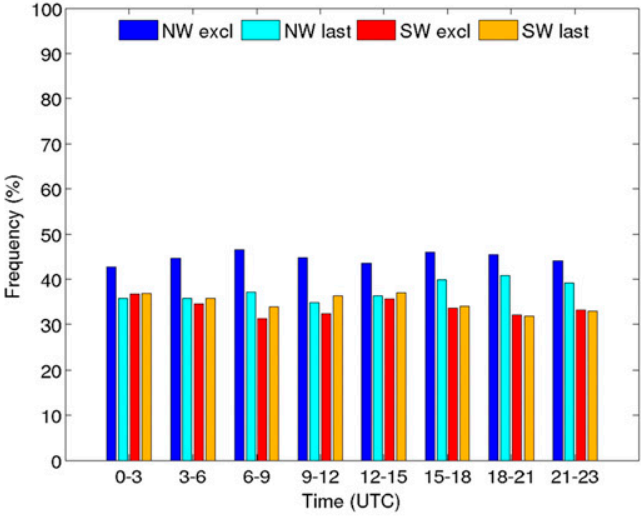

(b) Rejected day sets - VHF 3000 m

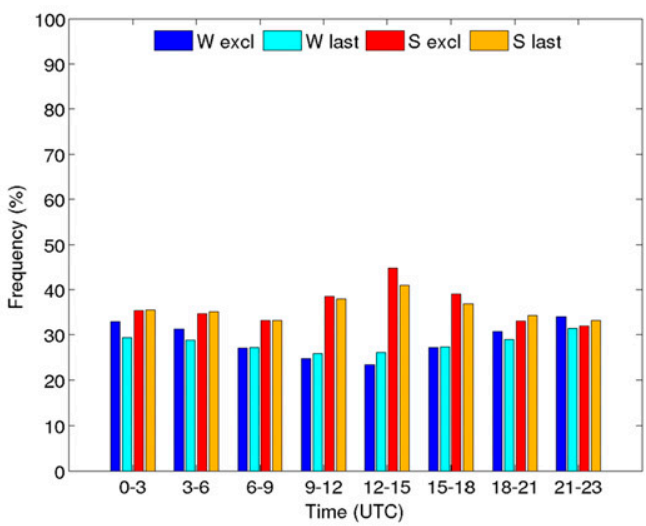

(d) Rejected day sets - Surface PDM

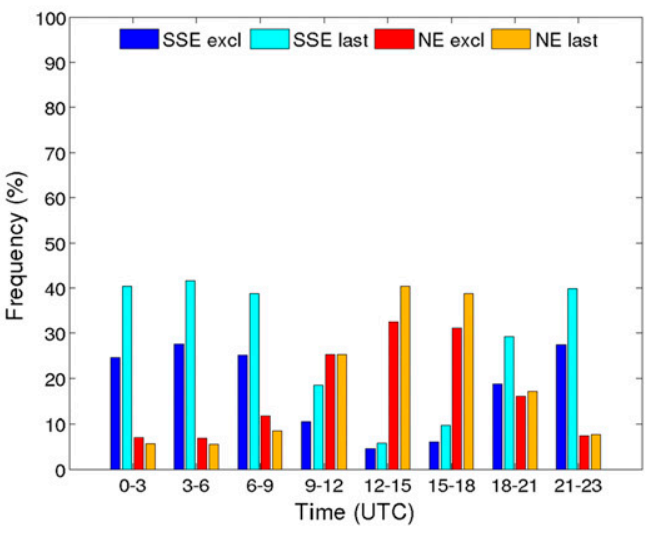

(f) Rejected day sets - Surface CRA

FIG. 12. Frequency of wind direction in three-hour intervals for (left) selected and (right) unselected days at the three measurement locations: (a),(b) VHF $3000 \mathrm{~m}$, (c),(d) PDM, and (e),(f) CRA surface. Only wind direction sectors that are typical of thermally induced winds at each site are shown (see the inserted legends, Fig. 2, and the text for details). Over denotes the overlap day set (201 days), excl is for the excluded day set (1096 days), and first and last are the first 200 and last 900 days, respectively, in the day ranking of method 3. 
Surface wind at CRA shows occurrences that follow a marked diurnal cycle for both the overlap and first sets (Fig. 12e). However, the cycle amplitude for the overlap set is significantly larger. Frequencies reaching nearly $90 \%$ are due to the method- 2 construction. Surface westerly winds at CRA are actually very frequent but are discarded by method 2. Indeed, the west sector (not shown in the histogram) represents less than $10 \%$ of wind directions in the overlap set, whereas it accounts for $45 \%$ of days at night and $30 \%$ in daytime for the first selection. Figure $12 \mathrm{f}$ shows the occurrences for the rejected sets. Westerly winds (representing around $65 \%$ and $55 \%$ of the excluded and last sets, respectively; not shown) are constant through the day. Diurnal cycles remain visible in the southeasteast sectors for rejected sets, corresponding to days with wind characteristics approaching but not meeting the filter criteria in method 2 (false negatives).

\section{e. Atmospheric composition diurnal cycles}

In this section, we focus on the impact of thermally driven circulations on the atmospheric composition at the PDM observatory. As explained in section 1, these thermal processes have a direct influence on measurements of pollutants at high-altitude stations, evidenced by concentration variations along diurnal cycles. Here, we investigate diurnal composites of the selected ("sel1," "sel2," and "sel3") and unselected ("unsel1," "unsel2," and "unsel3") day sets from the three methods, to evaluate the impact of the thermal circulation and to compare results obtained by the different methods. Figure 13 presents the diurnal composites of gas and aerosol concentrations for the six day sets. Because of the asymmetry of statistical distributions, especially for aerosol related variables, median values were considered instead of means to compute the diurnal composites. The numbers of days with available data used to calculate the composites are presented in Table 3.

It is clear at first glance that the mole fractions of the gaseous species (ozone, carbon monoxide, methane, and carbon dioxide) present marked diurnal cycles for the three selected sets (red curves). In daytime (1200-1500), we observe an increase of $\mathrm{CO}$ and $\mathrm{CH}_{4}$ and a decrease of $\mathrm{O}_{3}$ and $\mathrm{CO}_{2}$. As explained in section 1, partial mixing of free-tropospheric air with low-level air rich in $\mathrm{CO}$ and $\mathrm{CH}_{4}$ but depleted in $\mathrm{O}_{3}$ and $\mathrm{CO}_{2}$, explains the observed fluctuations well (Tsamalis et al. 2014). The diurnal cycles are absent or much more attenuated for the unselected sets (blue curves). These results reveal the direct anabatic influence on pollutants measurements at PDM and illustrate the overall efficiency of the three detection methods to discriminate this influence.

In more detail, the measured $\mathrm{O}_{3}$ concentration (Fig. 13a) shows no diurnal variation for the unsel 3 set and weak variations (about $2 \mathrm{ppb}$ ) for the unsel1 and unsel2 sets, whereas the median diurnal cycles vary with amplitudes of 4,3 , and 6 ppb for the sel1, sel2, and sel3 sets, respectively. These results are consistent with previous studies. Gheusi et al. (2011) showed amplitudes of diurnal oscillations of ozone at PDM as large as $8-10 \mathrm{ppb}$ for a selection of thermally driven days during the period 13 June-7 July 2005. Throughout this period the mean daytime values were, on average, 2-3 ppb lower than at night. Marenco (1986) presented the ozone mean diurnal cycle for each month of 1982 . The diurnal cycles had their maximum amplitude in summer $(8 \mathrm{ppb}$, from $44 \mathrm{ppb}$ in daytime to $52 \mathrm{ppb}$ at night) and minimum amplitude in winter ( $3 \mathrm{ppb}$, from 40 to $43 \mathrm{ppb}$ ). Beyond this, our measured background (i.e., nighttime) $\mathrm{O}_{3}$ concentrations are higher during selected days (between 50 and $52 \mathrm{ppb}$ ) than during unselected days (between 46 and $49 \mathrm{ppb}$ ). Marenco (1986) also presented the seasonal variation of ozone at PDM in 1982. This revealed two maxima: in spring (58 ppb) and in summer (52 ppb), showing an increase of $60 \%$ and $40 \%$ relative to the minimum obtained in winter (36 ppb). Chevalier et al. (2007) showed the seasonal variation of ozone at PDM over the period 2001-04. They reported a minimum in winter (45 ppb) and a maximum in summer (55-65 ppb). Gheusi et al. (2006) confirmed these observations for 2005 and showed a background $\mathrm{O}_{3}$ concentration with a minimum in winter and an increase in spring that reached a value of 15-30 ppb higher than in winter. Given the seasonal distributions of the days from the different sets (Fig. 11), our results on ozone background levels are consistent with the expected seasonal variations. Because most of the selected days occur in summer, composites from the selected day sets present the highest background $\mathrm{O}_{3}$ concentration. On the contrary, the unselected sets, most prevalent in winter, present the lowest background $\mathrm{O}_{3}$ concentration. However, we obtained smaller differences in background concentrations than in seasonal means, since a nonnegligible proportion of selected days occurred in winter.

For the measured CO concentration shown in Fig. 13b, we observe almost no diurnal variation for the unsel1 and unsel 3 sets, whereas the median diurnal cycles exhibit amplitudes of $6 \mathrm{ppb}$ and $5 \mathrm{ppb}$ for the sel1 and sel3 sets, respectively. The method- 2 selection (sel2 set) presents a weaker diurnal variation ( $\sim 3 \mathrm{ppb})$. A residual cycle ( $2 \mathrm{ppb}$ ) is still present for the unsel2 set, again illustrating the limitation of method 2 when discriminating the anabatic influence at PDM. These results are again in agreement with previous studies on $\mathrm{CO}$ diurnal and seasonal cycles (Marenco 1986; Gheusi et al. 2006, 2011; Forrer et al. 2000), despite lower values in our study. Forrer et al. (2000) used measurements from June 1996 to November 1997 at 


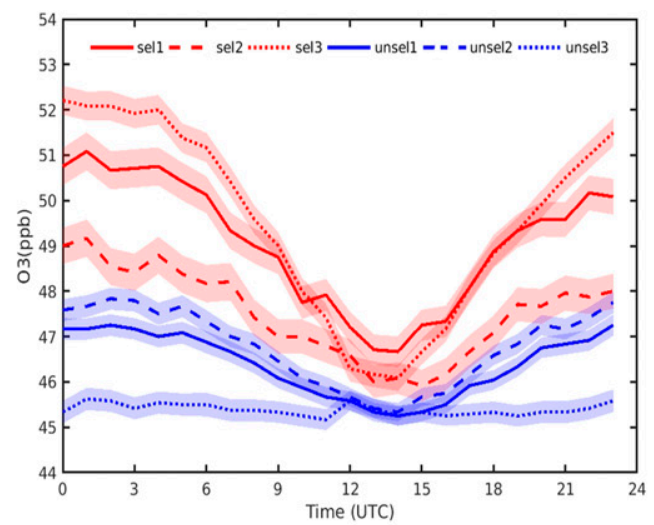

(a) $\mathrm{O}_{3}$

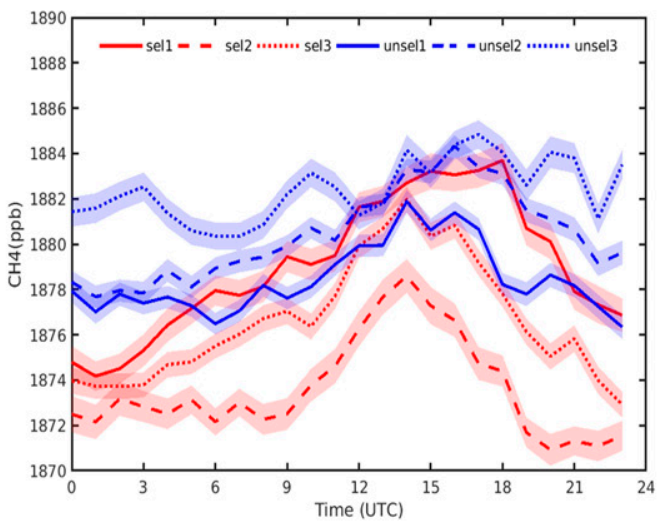

(c) $\mathrm{CH}_{4}$

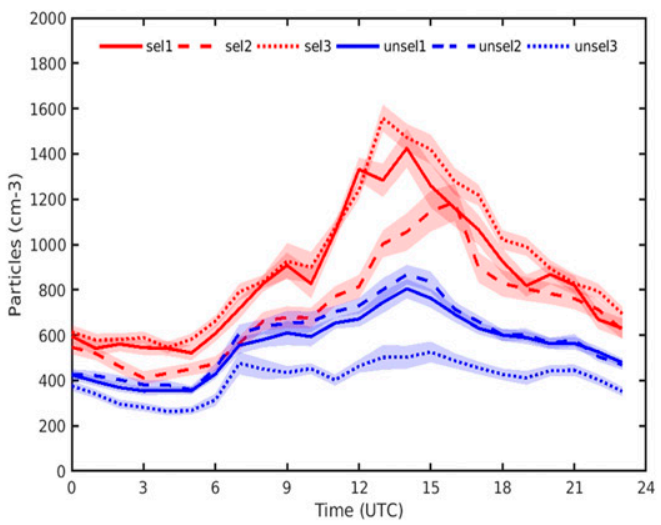

(e) Aerosol number conc.

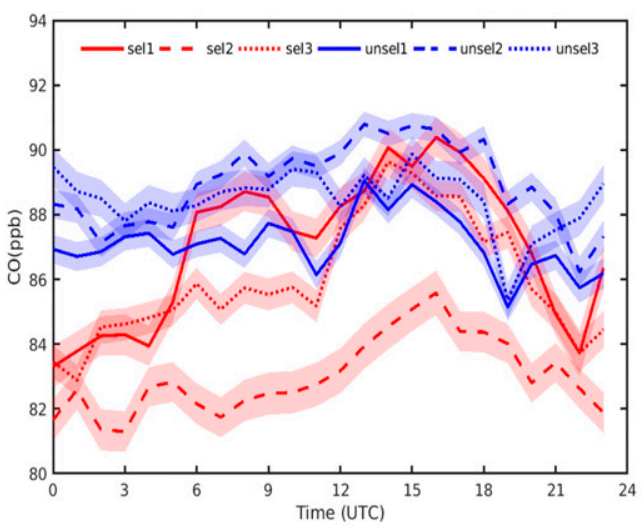

(b) $\mathrm{CO}$

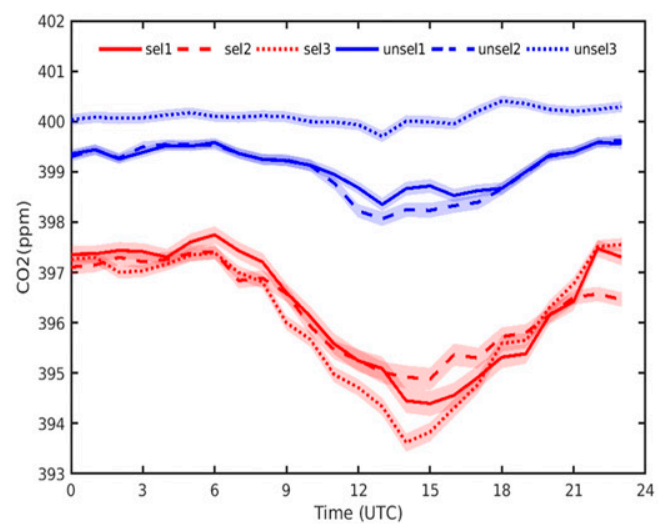

(d) $\mathrm{CO}_{2}$

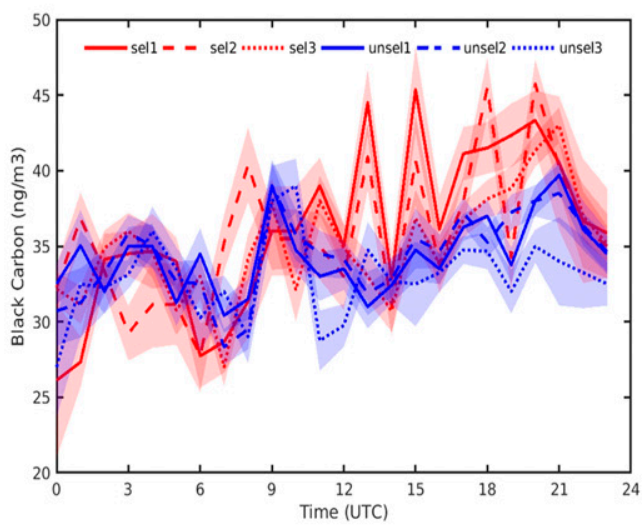

(f) EqBC mass conc.

FIG. 13. Diurnal composite of median concentrations (curves) and associated standard errors (shading) for (a) ozone, (b) carbon monoxide, (c) methane, (d) carbon dioxide, (e) total suspended particles, and (f) equivalent black carbon, as measured at PDM for different day sets. Labels sel1, sel2, and sel3 denote the sets of days selected by the three methods ( 939 most-anabatic days for method 3), and unsel1, unsel2, and unsel3 denote the sets of unselected (i.e., rejected) days. 
TABLE 3. Number of days with available data used to calculate median diurnal cycles in Fig. 13.

\begin{tabular}{|c|c|c|c|c|c|c|}
\hline & \multicolumn{2}{|c|}{ Method 1} & \multicolumn{2}{|c|}{ Method 2} & \multicolumn{2}{|c|}{ Method 3} \\
\hline & Sel1 & Unsel1 & Sel2 & Unsel2 & Sel3 & Unsel3 \\
\hline $\mathrm{O}_{3}$ & 514 & 1352 & 512 & 1354 & 842 & 884 \\
\hline $\begin{array}{l}\text { Greenhouse gases } \\
\qquad\left(\mathrm{CO} ; \mathrm{CO}_{2} ; \mathrm{CH}_{4}\right)\end{array}$ & 81 & 185 & 70 & 195 & 148 & 110 \\
\hline $\begin{array}{l}\text { TSP no. } \\
\text { concentration }\end{array}$ & 143 & 388 & 138 & 393 & 255 & 245 \\
\hline $\begin{array}{l}\text { eqBC mass } \\
\text { concentration }\end{array}$ & 92 & 211 & 71 & 233 & 152 & 117 \\
\hline
\end{tabular}

the high-Alpine site Jungfraujoch to study the variability of CO. They observed diurnal cycles in summer and spring (amplitudes of 10 and $8 \mathrm{ppb}$, respectively), whereas winter and autumn were characterized by no diurnal variation. Gheusi et al. (2011) made comparable observations at PDM over the summer of 2005. They measured a mean diurnal cycle with a 10-ppb amplitude and observed amplitudes as large as $15 \mathrm{ppb}$ for individual thermally driven days. For the CO seasonal cycle, Marenco (1986), Forrer et al. (2000), and Gheusi et al. (2006) revealed a minimum background concentration in summer, caused by maximum reactivity with $\mathrm{OH}$ radicals (Granier et al. 2000). Then the concentration rose in autumn to reach a maximum value in late winter and early spring. The background $\mathrm{CO}$ concentrations in our selections are consistent with the seasonality, since they are lower for the selected days $(82-86 \mathrm{ppb})$ than for the unselected days (87-89 ppb).

Necki et al. (2003) and Lopez et al. (2015) presented studies on $\mathrm{CH}_{4}$ and $\mathrm{CO}_{2}$ diurnal and seasonal variations. Necki et al. (2003) reported carbon dioxide and methane observations from the continental mountain station Kasprowy Wierch in the Tatra Mountains of southern Poland over the period from 1994 to 2000. Lopez et al. (2015) also reported carbon dioxide and methane observations, but from Puy de Dôme station (central France) over three years (June 2010-June 2013). Both research groups reported a $\mathrm{CH}_{4}$ seasonal cycle with a minimum in summer and a maximum in spring, and a $\mathrm{CO}_{2}$ seasonal cycle with a minimum in summer and a maximum in winter. Moreover, they showed a diurnal cycle in summer for $\mathrm{CH}_{4}$ and $\mathrm{CO}_{2}$ (amplitude around $30 \mathrm{ppb}$ and $5 \mathrm{ppm}$, respectively), which was absent in winter. In line with their observations, we note no diurnal variations of $\mathrm{CO}_{2}$ for the unsel3 set, weak variations ( $1 \mathrm{ppm}$ ) for the unsel1 and unsel 2 sets, and higher variations (3 ppm) for the three selected sets (Fig. 13d). For $\mathrm{CH}_{4}$ (Fig. 13c), our results show lower diurnal cycle amplitudes for selected days than those presented in Necki et al. (2003) and Lopez et al. (2015). The median diurnal cycles for
$\mathrm{CH}_{4}$ present amplitudes of 9 and $8 \mathrm{ppb}$ for the sel1 and sel3 sets, respectively, and the unsel1 and unsel3 sets exhibit weak cycles ( 3 and 1 ppb, respectively). The method- 2 selections (sel2 and unsel2) still largely fail to discriminate days with or without anabatic influence at PDM (diurnal variations of about 5-6 ppb for both sets). Consistent with the seasonal background concentrations, $\mathrm{CH}_{4}$ and $\mathrm{CO}_{2}$ mixing ratios are lower for selected sets than for unselected sets. Methane median concentrations vary between 1878 and $1882 \mathrm{ppb}$ for unselected sets, whereas they are around $1874 \mathrm{ppb}$ for the selected sets. In the same way, carbon dioxide background concentrations reach 399-400 ppm on unselected days, whereas they are around $397 \mathrm{ppm}$ on selected days.

For aerosols, diurnal composites of $N$, as well as eqBC, are shown in Figs. 13e,f. As discussed in section 1, $N$ is generally not a reliable tracer of anthropogenic emission transport because of the possible occurrence of new particle formation in the mountain atmosphere. Nevertheless, the diurnal evolution of $N$ is here in phase with $\mathrm{CO}$ and $\mathrm{CH}_{4}$, showing a nighttime minimum and a maximum in the afternoon for the three selected sets. For the sell and sel3 sets in particular, $N$ more than doubles in daytime relative to nighttime values. For the unselected sets, the diurnal cycle is much more attenuated, and it is even flat for the unsel3 set (which corresponds to the most local criterion for anabatic influence detection). Obviously, $N$ evolves here as the gaseous boundary layer tracers $\left(\mathrm{CH}_{4}, \mathrm{CO}\right.$, and water vapor). This could suggest that events of new particle formation have a negligible impact in the present statistics for PDM. However, such a conclusion remains speculative without further characterization of the aerosol composition and size distribution, which is an ongoing work (first measurement campaign conducted at PDM in 2018). The literature suggests that the aerosol absorption coefficient is usually a more reliable tracer of the boundary layer influence than $N$ (e.g., Collaud Coen et al. 2018). This can be true, however, only if the regional boundary layer around a mountain observatory contains significantly more absorbing aerosols than the free troposphere. In Fig. 13f, the composites of eqBC (which is a proxy of the absorption coefficient) show no clear diurnal pattern for any day sets and are hardly distinguishable from each other. The values remain all between 25 and $45 \mathrm{ng} \mathrm{m}^{-3}$, which is well in the range of seasonal statistics reported for the Jungfraujoch by Bukowiecki et al. (2016) but is much lower than values recorded at the Nepal Climate Observatory (NCO-P), where a clear mean diurnal cycle of eqBC was evidenced (Venzac et al. 2008). The absence of diurnal cycle at PDM, even in the case of anabatic transport, suggests that the regional boundary layer is clean in absorbing aerosols, or at least that the low signal of absorbing black carbon (BC) from the boundary layer 
may be hidden in the non-BC absorbing components (e.g., terrigenous aerosol containing iron oxide, among other examples) of the free-tropospheric signal. As result, eqBC cannot be used as boundary layer tracer at PDM, and air masses with higher burden in absorbing aerosol, when detected at PDM, should be considered as particular events and studied specifically.

To conclude on the three methods, the sets selected by methods 1 and 3 (sel1 and sel3) are found to produce diurnal composites of atmospheric concentrations that are qualitatively and quantitatively similar. Both methods can thus be used to characterize the typical atmospheric evolution during anabatic days. The diurnal cycles from the method-2 selection (sel2) are qualitatively similar, but the method is less discriminating, and, in turn, the cycle amplitudes obtained are weaker; the background concentrations also differ because of different seasonality of the underlying data. Method 3 (day set unsel3) seems to be the most reliable to discard days during which anabatic transport has an impact on air composition at PDM. This is not surprising, because method 3 uses in situ measurements whereas the other two methods are nonlocal. Days with strong diurnal cycle in humidity are also days with strong diurnal cycles of other atmospheric species, and vice versa. Nevertheless, method 1 can be a valuable complement to method 3 when studying the export of boundary layer species into the lower free troposphere at regional scale, since method 3 is only partly effective to predict the existence of a return flow over the plain (Figs. 10c,e,f).

\section{Conclusions and perspectives}

The air composition measured at PDM is frequently affected by upward transport of boundary layer air in cases of thermally driven circulations at different scales. In this study, we define three independent methods for detecting thermally induced circulations at three key locations in the plain-to-mountain circulation cell: within the altitude return flow above the plain (method 1$)$, close to the surface in the plain (method 2), and close to the surface at the mountaintop (method 3). We applied the three methods to a 2006-15 dataset collected at P2OA. A return flow at altitude was detected on $27.4 \%$ of days (method 1$)$; surface thermally driven winds were found in the plain on $27.5 \%$ of days (method 2); anabatic transport to the PDM was detected by method 3 for $47.3 \%$ of days over the period.

The three corresponding day sets only partly overlap, mainly because of the differing points of view implicit in the methods: local thermal winds may occur close to the surface in the plain without obvious return flow at
$3000 \mathrm{~m}$; a large-scale circulation may also be detected at altitude without a clear signal near the surface in the plain; anabatic influence experienced at PDM may result from local upslope or up-valley transport only, without a signature at larger scale. Detection failures (false positives or negatives) by the complex automatic algorithms can also partly explain inconsistencies among the sets.

For the seasonality of the days selected by the three methods, method 2 differs from the other two. Days selected by methods 1 and 3 have a maximum occurrence rate during the warm season and a minimum one in winter, whereas the days selected by method 2 are more uniformly distributed over the whole year, despite a maximum in autumn and a minimum in late spring and early summer. An explanation may be provided by a climatological maximum of moisture and cloudiness affecting the surface conditions over the foothills in May, June, and July, whereas in autumn and winter anticyclonic dry air is more frequent in the Pyrenean foreland and may lead to weak thermally driven winds, even in cold air. However, $75 \%$ of the overlap set (days selected by both methods 1 and 2) fall into the anabatic category from method 3, and the diurnal variations of wind for the different sets show global consistency among the three approaches.

Wind direction diurnal cycles, specific to thermally induced winds at each measurement location, are observed for the anabatic day sets from all methods. This supports the hypothesis of a frequent well-developed circulation cell composed of a plain-to-mountain surface flow and a compensatory return flow at altitude. Composites of the VHF wind profiles show that the return flow occurs typically between 2500 and $4000 \mathrm{~m}$, is maximum between 1200 and 1500 UTC, and has a mean maximum intensity of $2 \mathrm{~m} \mathrm{~s}^{-1}$. In the sets of rejected days, we observe no diurnal variation at $3000 \mathrm{~m}$ above CRA, whereas weaker diurnal cycles in surface wind persist in the statistics both at PDM and CRA (section 4d and Fig. 12). This can be explained by the persistence of local thermally induced surface flow even in the absence of regional plainmountain circulation. Even though return flows often coincide with surface anabatic winds at CRA, our results reveal that circulations may also occur independently at altitude and near the surface.

The impact of anabatic transport on atmospheric composition measured at the PDM observatory is also investigated. Diurnal cycles in relation to the phenomenon are observed in selected days, whereas no (or attenuated) diurnal variations are detected in unselected days. During thermally driven days, daytime ozone and carbon dioxide levels are found to be lower than at night. This is the result of upward transport of air depleted in ozone and carbon 
dioxide from the lower levels, as confirmed by the diurnal evolution of gaseous boundary layer markers (carbon monoxide and methane), showing a nocturnal minimum and a diurnal maximum. At first glance, the total aerosol number concentration behaves as the gaseous boundary layer markers; however, the possibility of new particle formation (NPF) in the close environment of PDM may blur the statistics. The instrumentation available in 200615 did not make it possible to identify NPF events and specify their statistical impact, but new instruments operated at PDM from 2018 should fill this gap. The measurements of light absorption by aerosols cannot be interpreted in terms of anabatic transport as they present no differences between selected and unselected sets. This suggests that the contrast between the regional boundary layer and the free troposphere is weak in terms of absorbing aerosol burden. In general, our study that is based on a data series that is almost 10 years long supports previous results obtained from shorter data series at PDM, in terms of cycle phase, amplitude, and mean concentrations. These results are also in agreement with previous studies at other high-altitude sites. The results obtained here confirm a climatological impact of anabatic transport on daytime measurements.

Despite differing points of views resulting in day selections that, to some extent, do not match, the three methods provide datasets having mostly similar characteristics. However, method 2 seems to be the least discriminating with regard to the impact on air composition at PDM, since selected days correspond to local thermally induced winds at CRA. Concentration composites based on day selections from methods 1 and 3 present similar characteristics, but method 3 seems to be the most reliable to discard days during which the thermally driven circulation has an impact on air composition at PDM. However, method 3 does not guarantee the existence of an export flow over the plain, and method 1 can be a valuable complement to study more specifically the export of boundary layer species into the regional free troposphere. In conclusion, the three detection methods give different point of views and better understanding of the thermally driven circulations and their influences on atmospheric composition measured at the PDM observatory.

The limitations of the detection methods should be overcome in the future by considering complementary observations or analysis strategies. The VHF profiler data used in method 1 do not detect the low-level flow, but UHF profiler data series have become available more recently at the CRA, and data over commonly covered periods could help us in this respect. The synoptic forcing conditions and their influences on thermal winds detected by method 2 should be examined with attention. For instance, an approach is currently being developed to automatically extract weak synoptic forcing conditions (Román-Cascón et al. 2019). In the continuation of the study of anabatic influences at PDM, a radon detector was installed in autumn 2017. Radon measurements will allow the continental surface influences at the PDM observatory to be quantified, in a better way than with specific humidity as in our method 3 , because radon, a chemically passive tracer with a well-characterized decay rate, has much simpler dynamics in the atmosphere than water vapor has. Other strategies deserve to be considered also: the use of a backward particle dispersion model at finescale and the study of horizontal pressure gradients between the plain and the mountain.

Acknowledgments. The first author's salary was partly funded by the BLLAST project (French ANR). We acknowledge the Pyrenean Platform for Observation of the Atmosphere (http://p2oa.aero.obs-mip.fr) for the data collected at the Centre de Recherche Atmosphérique and at the Pic du Midi. P2OA facilities and staff are funded and supported by the Observatoire Midi-Pyrénées (University Paul Sabatier, Toulouse, France) and the Centre National de la Recherche Scientifique (CNRS). Similarly, we acknowledge Météo-France for data from the weather station set up at CRA. We acknowledge the SNO ICOSFrance-Atmosphere for supporting greenhouse gas observations at PDM and data collection, processing, and dissemination. We also thank P. Barneoud, S. Beck, P. Lafrique, and B. Lagnoux for their study on thermally induced surface flows at CRA during an internship. Last, we thank the three anonymous reviewers for their careful and constructive reviews that helped us to greatly improve our paper.

\section{REFERENCES}

Aneja, V. P., C. S. Claiborn, Z. Li, and A. Murthy, 1994: Trends, seasonal variations, and analysis of high-elevation surface nitric acid, ozone, and hydrogen peroxide. Atmos. Environ., 28, 1781-1790, https://doi.org/10.1016/1352-2310(94)90140-6.

Arnott, W. P., K. Hamasha, H. Moosmuller, P. J. Sheridan, and J. Ogren, 2005: Towards aerosol light-absorption measurements with a 7-wavelength aethalometer: Evaluation with a photoacoustic instrument and 3-wavelength nephelometer. Aerosol Sci. Technol., 39, 17-29, https://doi.org/10.1080/027868290901972.

Atlas, E. L., and B. A. Ridley, 1996: The Mauna Loa observatory photochemistry experiment: Introduction. J. Geophys. Res., 101, 14 531-14 541, https://doi.org/10.1029/96JD01203.

Barneoud, P., S. Beck, P. Lafrique, and B. Lagnoux, 2010: Climatologie sur le site instrumenté du laboratoire d'aérologie (Climatology for the aerology laboratory instrumented site). Université Paul Sabatier Toulouse III Rep., 19 pp., http://p2oa.aero.obs-mip.fr/ spip.php?article $449 \&$ lang $=$ fr.

Bianchi, F., and Coauthors, 2016: New particle formation in the free troposphere: A question of chemistry and timing. Science, 352, 1109-1112, https://doi.org/10.1126/science.aad5456. 
Bonasoni, P., A. Stohl, P. Cristofanelli, F. Calzolari, T. Colombo, and F. Evangelisti, 2000: Background ozone variations at Mt. Cimone station. Atmos. Environ., 34, 5183-5189, https:// doi.org/10.1016/S1352-2310(00)00268-5.

Bossert, J. E., and W. R. Cotton, 1994: Regional-scale flows in mountainous terrain. Part I: A numerical and observational comparison. Mon. Wea. Rev., 122, 1449-1471, https://doi.org/ 10.1175/1520-0493(1994)122<1449:RSFIMT>2.0.CO;2.

Boulon, J., K. Sellegri, M. Hervo, D. Picard, J.-M. Pichon, P. Fréville, and P. Laj, 2011: Investigation of nucleation events vertical extent: A long term study at two different altitude sites. Atmos. Chem. Phys., 11, 5625-5639, https://doi.org/10.5194/ acp-11-5625-2011.

Brooks, B.-G. J., A. R. Desai, B. B. Stephens, D. R. Bowling, S. P. Burns, A. S. Watt, S. L. Heck, and C. Sweeney, 2012: Assessing filtering of mountaintop $\mathrm{CO} 2$ mole fractions for application to inverse models of biosphere-atmosphere carbon exchange. Atmos. Chem. Phys., 12, 2099-2115, https://doi.org/10.5194/ acp-12-2099-2012.

Bukowiecki, N., and Coauthors, 2016: A review of more than 20 years of aerosol observation at the high altitude research station Jungfraujoch, Switzerland (3580 m asl). Aerosol Air Qual. Res., 16, 764-788, https://doi.org/10.4209/aaqr.2015.05.0305.

Calvert, J. G., 1990: Glossary of atmospheric chemistry terms (Recommendations 1990). Pure Appl. Geophys., 62, 2167-2219.

Campistron, B., Y. Pointin, F. Lohou, and J.-P. Pagès, 1999: Aspect sensitivity of VHF radar echoes observed in the middle and upper troposphere during the passage of a cut-off low. Radio Sci., 34, 667-779, https://doi.org/10.1029/1998RS900032.

, D. Despaux, M. Lothon, V. Klaus, Y. Pointin, and M. Mauprivez, 2001: A partial $45 \mathrm{MHz}$ sky temperature map obtained from the observations of five ST radars. Ann. Geophys., 19, 863-871, https://doi.org/10.5194/angeo-19-863-2001.

Chambers, S., W. Zahorowski, A. Williams, J. Crawford, and A. Griffiths, 2013: Identifying tropospheric baseline air masses at Mauna Loa Observatory between 2004 and 2010 using Radon-222 and back trajectories. J. Geophys. Res. Atmos., 118, 992-1004, https://doi.org/10.1029/2012JD018212.

Chevalier, A., and Coauthors, 2007: Influence of altitude on ozone levels and variability in the lower troposphere: A groundbased study for western Europe over the period 2001-2004. Atmos. Chem. Phys., 7, 4311-4326, https://doi.org/10.5194/ acp-7-4311-2007.

Collaud-Coen, M., E. Weingartner, M. Furger, S. Nyeki, A. S. H. Prévôt, M. Steinbacher, and U. Baltensperger, 2011: Aerosol climatology and planetary boundary influence at the Jungfraujoch analyzed by synoptic weather types. Atmos. Chem. Phys., 11, 5931-5944, https://doi.org/10.5194/acp-11-5931-2011.

— influencing aerosol observations at high altitude stations. Atmos. Chem. Phys., 18, 12 289-12 313, https://doi.org/10.5194/ acp-18-12289-2018.

Cristofanelli, P., and Coauthors, 2013: Analysis of summer ozone observations at a high mountain site in central Italy (Campo Imperatore, 2388 m a.s.l.). Pure Appl. Geophys., 170, 1985-1999, https://doi.org/10.1007/s00024-012-0630-1.

Crosson, E. R., 2008: A cavity ring-down analyzer for measuring atmospheric levels of methane, carbon dioxide, and water vapor. Appl. Phys., 92B, 403-408, https://doi.org/10.1007/ s00340-008-3135-y.

DeWekker, S. F., A. Ameen, G. Song, B. B. Stephens, A. G. Hallar, and I. B. McCubbin, 2009: A preliminary investigation of boundary layer effects on daytime Atmospheric $\mathrm{CO}_{2}$ concentrations at a mountaintop location in the Rocky Mountains. Acta Geophys., 57, 904-922, https://doi.org/10.2478/s11600-009-0033-6.

Diaz, J., A. Ezcurra, J. Saenz, B. Campistron, G. Ibarra, and F. Saïd, 2010: Atmospheric tides over the Pyrenees: Observational study and numerical simulation. Quart. J. Roy. Meteor. Soc., 136, 1263-1274, https://doi.org/10.1002/qj.626.

Dosio, A., S. Galmarini, and G. Graziani, 2002: Simulation of the circulation and related photochemical ozone dispersion in the Po plains (northern Italy): Comparison with the observations of a measuring campaign. J. Geophys. Res., 107, 8189, https:// doi.org/10.1029/2000JD000046.

Ezcurra, A., B. Benech, A. Echelecou, J. M. Santamaría, I. Herrero, and E. Zulueta, 2013: Influence of local air flow regimes on the ozone content of two Pyrenean valleys. Atmos. Environ., 74, 367-377, https://doi.org/10.1016/j.atmosenv.2013.03.051.

Fischer, H., and Coauthors, 1998: Trace gas measurements during the oxidizing capacity of the tropospheric atmosphere campaign 1993 at Izaña. J. Geophys. Res., 103, 13 505-13 518, https://doi.org/10.1029/97JD01497.

__ , and Coauthors, 2003: Ozone production and trace gas correlations during the June 2000 MINATROC intensive measurement campaign at Mt. Cimone. Atmos. Chem. Phys., 3, 725-738, https://doi.org/10.5194/acp-3-725-2003.

Forrer, J., R. Ruttimann, D. Schneiter, A. Fischer, B. Buchmann, and P. Hofer, 2000: Variability of trace gases at the high-Alpine site Jungfraujoch caused by meteorological transport processes. J. Geophys. Res., 105, 12 241-12 251, https://doi.org/10.1029/ 1999JD901178.

García, M. I., S. Rodríguez, Y. González, and R. D. García, 2014: Climatology of new particle formation at Izaña mountain GAW Observatory in the subtropical North Atlantic. Atmos. Chem. Phys., 14, 3865-3881, https://doi.org/10.5194/ acp-14-3865-2014.

Gheusi, F., and Coauthors, 2006: Ozone et pollution atmosphérique à grande échelle (1): Le réseau de surveillance PAES Meteorologie, 58, 30-35, https://doi.org/10.4267/2042/18206.

— , and Coauthors, 2011: Pic 2005, a field campaign to investigate low-tropospheric ozone variability in the Pyrenees. Atmos. Res. 101, 640-665, https://doi.org/10.1016/j.atmosres.2011.04.014. , and Coauthors, 2016: La campagne Pic 2010: Observation, modélisation et quantification de la ventilation orographique au-dessus des Pyrénées (The Pic 2010 campaign: Observation, modeling, and quantification of orographic ventilation over the Pyrenees). Presentation, Atmospheric Modeling Workshops (AMA): Observatory Data and Modeling, Météo-France, 55 pp., http://www.meteo.fr/cic/meetings/2016/AMA/presentations/ 2016/AMA2016_lundi/11-pres_Gheusi_Pic2010_split.pdf.

Graf, M., M. Kossmann, K. Trusilova, and G. Mühlbacher, 2016: Identification and climatology of alpine pumping from a regional climate simulation. Front. Earth Sci., 4, 5, https://doi.org/10.3389/ feart.2016.00005.

Granier, C., G. Pétron, J.-F. Müller, and G. Brasseur, 2000: The impact of natural and anthropogenic hydrocarbons on the tropospheric budget of carbon monoxide. Atmos. Environ., 34 5255-5270, https://doi.org/10.1016/S1352-2310(00)00299-5.

Griffiths, A. D., F. Conen, E. Weingartner, L. Zimmermann, S. Chambers, A. G. Williams, and M. Steinbacher, 2014: Surface-to-mountaintop transport characterised by radon observations at the Jungfraujoch. Atmos. Chem. Phys., 14, 12 763-12 779, https://doi.org/10.5194/acp-14-12763-2014.

Haiden, T., 2003: On the pressure field in the slope wind layer. J. Atmos. Sci., 60, 1632-1635, https://doi.org/10.1175/ 1520-0469(2003)60<1632:OTPFIT >2.0.CO;2. 
Hallar, A. G., R. Petersen, I. B. McCubbin, D. Lowenthal, S. Lee, E. Andrews, and F. Yu, 2016: Climatology of new particle formation and corresponding precursors at storm peak laboratory. Aerosol Air Qual. Res., 16, 816-826, https://doi.org/ 10.4209/aaqr.2015.05.0341.

Henne, S., M. Furger, and A. S. H. Prévôt, 2005: Climatology of mountain venting induced elevated moisture layers in the lee of the Alps. J. Appl. Meteor., 44, 620-633, https://doi.org/ 10.1175/JAM2217.1.

_ J. Jlausen, W. Junkermann, J. M. Kariuki, J. O. Aseyo, and B. Buchmann, 2008: Representativeness and climatology of carbon monoxide and ozone at the global GAW station Mt. Kenya in equatorial Africa. Atmos. Chem. Phys., 8, 31193139, https://doi.org/10.5194/acp-8-3119-2008.

_ D. Brunner, D. Folini, S. Solberg, J. Klausen, and B. Buchmann, 2010: Assessment of parameters describing representativeness of air quality in-situ measurement sites. Atmos. Chem. Phys., 10, 3561-3581, https://doi.org/10.5194/acp-10-3561-2010.

Herrmann, E., and Coauthors, 2015: Analysis of long-term aerosol size distribution data from Jungfraujoch with emphasis on free tropospheric conditions, cloud influence, and air mass transport. J. Geophys. Res. Atmos., 120, 9459-9480, https://doi.org/ 10.1002/2015JD023660.

Jiménez, M. A., and J. Cuxart, 2014: A study of the nocturnal flows generated in the north side of the Pyrenees. Atmos. Res., 145146, 244-254, https://doi.org/10.1016/j.atmosres.2014.04.010.

__ and - 2016: The influence of the Aure Valley on the BL features observed during BLLAST. BLLAST Workshop, Wageningen, Netherlands, SEDOO, http://bllast.sedoo.fr/ workshops/february2016/presentations/MariaAJimenez mesoscale-circulation.pdf.

Keeling, C. D., R. B. Bacastow, A. E. Bainbridge, C. A. Ekdahl, P. R. Guenther, L. S. Waterman, and J. F. S. Chin, 1976: Atmospheric carbon dioxide variations at Mauna Loa Observatory, Hawaii. Tellus, 28, 538-551, https://doi.org/10.1111/ j.2153-3490.1976.tb00701.x.

Lin, J. C., D. V. Mallia, D. Wu, and B. B. Stephens, 2017: How can mountaintop $\mathrm{CO}_{2}$ observations be used to constrain regional carbon fluxes? Atmos. Chem. Phys., 17, 5561-5581, https:// doi.org/10.5194/acp-17-5561-2017.

Lopez, M., M. Schmidt, M. Ramonet, J.-L. Bonne, A. Colomb, V. Kazan, P. Laj, and J.-M. Pichon, 2015: Three years of semicontinuous greenhouse gas measurements at the Puy de Dôme station (central France). Atmos. Meas. Tech., 8, 3941-3958, https://doi.org/10.5194/amt-8-3941-2015.

Lugauer, M., and P. Winkler, 2005: Thermal circulation in South Bavaria-Climatology and synoptic aspects. Meteor. Z., 14, 15-30, https://doi.org/10.1127/0941-2948/2005/0014-0015.

Macdonald, A. M., K. G. Anlauf, W. R. Leaitch, E. Chan, and D. W. Tarasick, 2011: Interannual variability of ozone and carbon monoxide at the Whistler high elevation site: 2002-2006. Atmos. Chem. Phys., 11, 11 431-11 446, https://doi.org/10.5194/ acp-11-11431-2011.

Marenco, A., 1986: Variations of $\mathrm{CO}$ and $\mathrm{O}_{3}$ in the troposphere: Evidence of $\mathrm{O}_{3}$ photochemistry. Atmos. Environ., 20, 911-918, https://doi.org/10.1016/0004-6981(86)90275-1.

Mendonca, B. G., 1969: Local wind circulation on the slopes of Mauna Loa. J. Appl. Meteor., 8, 533-541, https://doi.org/10.1175/15200450(1969)008<0533:LWCOTS > 2.0.CO;2.

Naja, M., S. Lal, and D. Chand, 2003: Diurnal and seasonal variabilities in surface ozone at a high altitude site $\mathrm{Mt} \mathrm{Abu}\left(24.6^{\circ} \mathrm{N}\right.$, $72.7^{\circ} \mathrm{E}, 1680 \mathrm{~m}$ asl) in India. Atmos. Environ., 37, 4205-4215, https://doi.org/10.1016/S1352-2310(03)00565-X.
Necki, J., M. Schmidt, K. Rozanski, M. Zimnoch, A. Korus, J. Lasa, R. Graul, and I. Levin, 2003: Six-year record of atmospheric carbon dioxide and methane at a high-altitude mountain site in Poland. Tellus, 55B, 94-104, https://doi.org/10.1034/j.16000889.2003.01446.x.

Neitola, K., E. Asmi, M. Komppula, A.-P. Hyvärinen, T. Raatikainen, T. S. Panwar, V. P. Sharma, and H. Lihavainen, 2011: New particle formation infrequently observed in Himalayan foothillsWhy? Atmos. Chem. Phys., 11, 8447-8458, https://doi.org/10.5194/ acp-11-8447-2011.

Obrist, D., A. Hallar, I. McCubbin, B. Stephens, and T. Rahn, 2008: Atmospheric mercury concentrations at Storm Peak Laboratory in the Rocky Mountains: Evidence for long-range transport from Asia, boundary layer concentrations, and plant mercury uptake. Atmos. Environ., 42, 7579-7589, https://doi.org/10.1016/ j.atmosenv.2008.06.051.

Oltmans, S. J., and H. Levy II, 1994: Surface ozone measurements from a global network. Atmos. Environ., 28, 9-24, https:// doi.org/10.1016/1352-2310(94)90019-1.

Parrish, D. D., and Coauthors, 2014: Long-term changes in lower tropospheric baseline ozone concentrations: Comparing chemistry-climate models and observations at northern midlatitudes. J. Geophys. Res. Atmos., 119, 5719-5736, https:// doi.org/10.1002/2013JD021435.

Poltera, Y., G. Martucci, M. Collaud Coen, M. Hervo, L. Emmenegger, S. Henne, D. Brunner, and A. Haefele, 2017: Pathfinderturb: An automatic boundary layer algorithm. development, validation and application to study the impact on in situ measurements at the Jungfraujoch. Atmos. Chem. Phys., 17, 10 051-10 070, https://doi.org/10.5194/acp-17-10051-2017.

Rampanelli, G., D. Zardi, and R. Rotunno, 2004: Mechanisms of up-valley winds. J. Atmos. Sci., 61, 3097-3111, https://doi.org/ 10.1175/JAS-3354.1.

Román-Cascón, C., and Coauthors, 2019: Observational characterization of diurnal mountain winds and their impacts on $\mathrm{CO}_{2}$ mixing ratios at three contrasting sites. Atmos. Res., 221, 111-126, https://doi.org/10.1016/j.atmosres.2019.01.019.

Rose, C., and Coauthors, 2015: Frequent nucleation events at the high altitude station of Chacaltaya (5240 m a.s.l.), Bolivia. Atmos. Environ., 102, 18-29, https://doi.org/10.1016/j.atmosenv.2014.11.015.

Rotach, M. W., A. Gohm, M. N. Lang, D. Leukauf, I. Stiperski, and J. S. Wagner, 2015: On the vertical exchange of heat, mass, and momentum over complex, mountainous terrain. Front. Earth Sci., 3, 1-14, https://doi.org/10.3389/feart.2015.00076.

Schuepbach, E., T. K. Friedli, P. Zanis, P. S. Monks, and S. A. Penkett, 2001: State space analysis of changing seasonal ozone cycles (1988-1997) at Jungfraujoch (3580 in above sea level) in Switzerland. J. Geophys. Res., 106, 20 413-20 427, https:// doi.org/10.1029/2000JD900591.

Schumann, U., 1990: Large-eddy simulation of the up-slope boundary layer. Quart. J. Roy. Meteor. Soc., 116, 637-670, https://doi.org/ 10.1002/qj.49711649307.

Sellegri, K., and Coauthors, 2010: Seasonal variations of aerosol size distributions based on long-term measurements at the high altitude Himalayan site of Nepal climate observatory-pyramid (5079 m), Nepal. Atmos. Chem. Phys., 10, $10679-10$ 690, https:// doi.org/10.5194/acp-10-10679-2010.

Staufer, J., and Coauthors, 2016: The first 1-year-long estimate of the Paris region fossil fuel $\mathrm{CO}_{2}$ emissions based on atmospheric inversion. Atmos. Chem. Phys., 16, 14 703-14 726, https://doi.org/ 10.5194/acp-16-14703-2016.

Steyn, D. G., S. F. J. De Wekker, M. Kossmann, and A. Martilli, 2013: Boundary layers and air quality in mountainous terrain. 
Mountain Weather Research and Forecasting: Recent Progress and Current Challenges, F. K. Chow, S. F. J. D. Wekker, and B. J. Snyder, Eds., Springer Atmospheric Sciences, 261-289.

Tsamalis, C., F. Ravetta, F. Gheusi, H. Delbarre, and P. Augustin, 2014: Mixing of free-tropospheric air with the lowland boundary layer during anabatic transport to a high altitude station. Atmos. Res., 143, 425-437, https://doi.org/10.1016/j.atmosres.2014.03.011.

Venzac, H., and Coauthors, 2008: High frequency new particle formation in the Himalayas. Proc. Natl. Acad. Sci. USA, 105, 15 66615 671, https://doi.org/10.1073/pnas.0801355105.

Vergeiner, I., and E. Dreiseitl, 1987: Valley winds and slope windsObservations and elementary thoughts. Meteor. Atmos. Phys., 36, 264-286, https://doi.org/10.1007/BF01045154.

Weingartner, E., H. Saathoff, M. Schnaiter, N. Streit, B. Bitnar, and U. Baltensperger, 2003: Absorption of light by soot particles: Determination of the absorption coefficient by means of aethalometers. J. Aerosol Sci., 34, 1445-1463, https://doi.org/ 10.1016/S0021-8502(03)00359-8.

Whiteman, C. D., 1990: Observation of thermally developed wind systems in mountainous terrain. Atmospheric Processes over Complex Terrain, W. Blumen, Ed., Amer. Meteor. Soc., $5-42$.

—, 2000: Mountain Meteorology: Fundamentals and Applications. Oxford University Press, $355 \mathrm{pp}$.

Yver Kwok, C., and Coauthors, 2015: Comprehensive laboratory and field testing of cavity ring-down spectroscopy analyzers measuring $\mathrm{H}_{2} \mathrm{O}, \mathrm{CO}_{2}, \mathrm{CH}_{4}$ and CO. Atmos. Meas. Tech., 8, 3867-3892, https://doi.org/10.5194/amt-8-3867-2015.

Zahorowski, W., and Coauthors, 2005: Radon-222 in boundary layer and free tropospheric continental outflow events at three ACE-Asia sites. Tellus, 57, 124-140, https://doi.org/10.3402/ tellusb.v57i2.16776.

Zardi, D., and C. D. Whiteman, 2013: Diurnal mountain wind systems. Mountain Weather Research and Forecasting, F. K. Chow, S. F. J. De Wekker, and B. J. Snyder, Eds., Springer Atmospheric Sciences, 35-119.

Zaveri, R. A., R. D. Saylor, L. K. Peters, R. McNider, and A. Song, 1995: A model investigation of summertime diurnal ozone behavior in rural mountainous locations. Atmos. Environ., 29, 1043-1065, https://doi.org/10.1016/1352-2310(94)00319-G. 